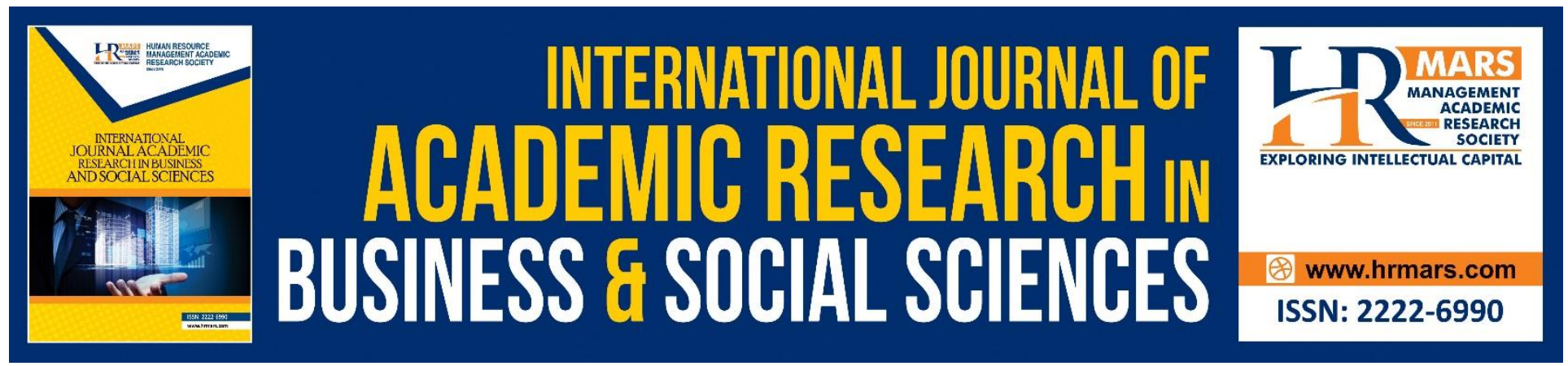

\title{
1MDB: Corporate Governance Going Berserk? Part II
}

\section{Azham Md. Ali}

To Link this Article: http://dx.doi.org/10.6007/IJARBSS/v9-i3/5757

DOI: $\quad 10.6007 /$ IJARBSS/v9-i3/5757

Received: 21 Jan 2019, Revised: 18 Feb 2019, Accepted: 30 March 2019

Published Online: 03 April 2019

In-Text Citation: (Ali, 2019)

To Cite this Article: Ali, A. M. (2019). 1MDB: Corporate Governance Going Berserk? Part II. International Journal of Academic Research in Business and Social Sciences, 9(3), 945-1004.

Copyright: (c) 2019 The Author(s)

Published by Human Resource Management Academic Research Society (www.hrmars.com)

This article is published under the Creative Commons Attribution (CC BY 4.0) license. Anyone may reproduce, distribute, translate and create derivative works of this article (for both commercial and non-commercial purposes), subject to full attribution to the original publication and authors. The full terms of this license may be seen

at: http://creativecommons.org/licences/by/4.0/legalcode

Vol. 9, No. 3, 2019, Pg. 945 - 1004

Full Terms \& Conditions of access and use can be found at http://hrmars.com/index.php/pages/detail/publication-ethics 


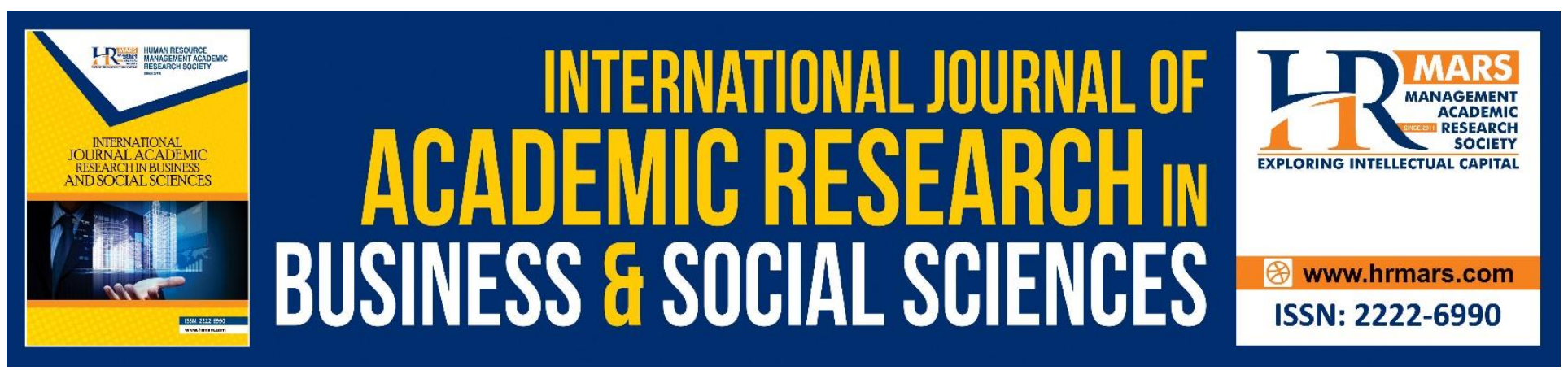

\title{
1MDB: Corporate Governance Going Berserk? Part II
}

\author{
Azham Md. Ali \\ Department of Accounting and Finance, Faculty of Management and Economics \\ Universiti Pendidikan Sultan Idris, 35900 Tanjong Malim Perak Malaysia \\ Email: azham@fpe.upsi.edu.my
}

\begin{abstract}
In contrast to the Part I that is comprised of three areas, the current Part II of the case study on 1MDB's corporate governance going berserk? dwells on two areas: either fraud or something else to explain the $1 \mathrm{MDB}^{\prime}$ 's quagmire; and, decision time for case readers. When it concerns the former, it comes in a total of seven parts with the first four on arguments used to explain away the debilitating goings on in the $1 M D B$ whereas the next one on fraud perpetration being the outright explanation. As for the last two parts, the penultimate one is concerned with the Public Account Committee (PAC) report on 1MDB and the last on Clause 117 of the 1MDB's memorandum and articles of association (M\&A). As for the latter section on decision time which is also the very last section of the whole of the case study combining Part I and Part II, its first half is concerned with the choice of a stance that readers of the case study can take in explaining the goings on in $1 \mathrm{MDB}$. Assuming that fraud is the stance taken, the section in its second half gives focus on a series of questions which readers may give attempt to answer.
\end{abstract}

Keywords: 1MDB, fraud, PAC report, Clause 117

\section{1MDB: A Case of Fraud Through and Through or Something Rather Innocence?}

To this day there are those believing that what was going on in 1MDB was no fraud at all - it was just the case of a wrong business model, lapses in governance and the like! Others however are quite adamant that it was fraud through and through. But perhaps most unbelievable than any of those stances denying that fraud had taken place emerged in the first quarter of 2015 courtesy of an individual closely connected to the $1 \mathrm{MDB}$ quagmire. This is mentioned next to be followed by the delineation of three other arguments used to explain away the 1MDB's debilitating saga: wrong business model, lapses of governance and no criminal doing. After having all the four arguments delineated, the section moves to the topic on fraud as the sole reason behind all the debilitations that had happened. Following the topic on fraud, there is a cautionary note regarding the report issued on $1 \mathrm{MDB}$ by the Public Accounts Committee (PAC) on April 7, 2016. Such note is important considering the fact that certain parts of the PAC report are mentioned in some areas of the present Part II of the case study. Next, the section comes to an end over the Clause 117 of the 1 MDB's memorandum and articles of association (M\&A). 


\subsection{A small matter! Nothing to be excited about...}

In March 2015 Malaysia and for that matter the rest of the world had to confront what was truly bizarre taking place on the sidelines of the 1Asean Entrepreneurship Summit 2015 when The Malaysian Insider reported ("1MDB a small issue", 2015): "1Malaysia Development Bhd (1MDB) is a small issue involving one company which is already undergoing restructuring, says Treasury secretary-general Dr Mohd Irwan Serigar Abdullah." (Emphasis added.) As mentioned in the very same news report, Mohd Irwan had this mentioned in response "... to a question on Fitch possibly downgrading the country's sovereign rating, which currently stands at A-, due to 1MDB's financial position."

Now, it should be worth noting the sharp reactions coming from some parties on Irwan's stance. Among them were the MP Tony Pua and the then news editor for KiniBiz Khairie Hisyam Aliman. For the former, in a news report by The Malaysian Insider the very next day, the following was mentioned among others ("1MDB's problems no small matter", 2015): “... it was irresponsible of Irwan to dismiss 1MDB's debt problems and its impact on Malaysia so lightly, Pua said." Also, in the very same news report a number of the 1MDB's litany of misconducts - coming from none other than Tony Pua himself - was raised:

Pua said $1 \mathrm{MDB}$, a wholly-owned subsidiary of the Finance Ministry, had gotten involved in dubious deals, such as the joint venture with PetroSaudi International, a company of little track record, where US\$700 million was eventually channeled to an unrelated third party. 1MDB had also overpaid for all its power plant acquisitions in its attempt to "diversify" its business. In turn, 1MDB took on even more debt, RM20.9 billion to acquire these overpriced RM12.1 billion worth of assets, Pua noted. He also highlighted another 1MDB investment in US\$3 billion of bonds for another joint venture in March 2013 which never materialised. "The money has since been abused for other purposes and 'invested' in funds which are not properly accounted for...

Tony Pua who was clearly unhappy with Irwan in "... brushing off concerns about the strategic investment fund's massive RM42 billion debts by giving the excuse that it was undergoing a restructuring process..." had also pointed out the following: that "... it was a dereliction of duty [for Irwan] to have let the government-owned fund slide into such a state" and that "... Irwan must explain how he allowed 1MDB to 'degenerate to such a deplorable financial state' and whether he had put any governance in place to save the state investment company from financial mismanagement." And, finally, in rounding everything up, Tony Pua was quoted to have raised the following penetrating questions:

Why didn't the Ministry of Finance appoint a representative in 1MDB's board of directors to ensure that all decisions by the 'strategic development fund' are made with the necessary transparency and due diligence? As the top civil servant looking after the interest of the tax-payers' monies, Tan Sri Irwan has failed in fulfilling his responsibilities with regards to the tens of billions of ringgit possibly lost in the $1 \mathrm{MDB}$ scandal, and he now has the cheek to tell Malaysians that it is 'a small issue involving just one company'? (Emphasis added.)

As for Khairie Hisyam's candid reaction for the Irwan's remark on 1MDB being a small issue involving a single company, check out the following (Khairie Hisyam, 2015): "Irwan's remarks are appalling given his important position at the Treasury and the scope of issues plaguing 1MDB, which are well-documented by various observers over the years including KiniBiz. ... Let us hope this statement by the Treasury's head is but a joke and, hopefully, does not reflect the Treasury's overall attitude towards the 1MDB 
problem." Note that in between these two lines, Khairie Hisyam had delineated the myriad of problems that $1 M D B$ had caused the country to suffer from:

There is the debt pile of nearly RM50 billion, there are the scandalous revelations by news portal Sarawak Report citing email exchanges between various parties concerning 1MDB's first joint venture way back in 2009... There are also the mismanagement and questionable investment and borrowing moves over the years, which among others led to a heart-wrenching cost-return mismatch from appallingly high interest rates against relatively sad returns on investment, billions of cash in the bank strangely unused despite urgent needs, and many more. Lest we forget, Putrajaya is bound to make good on at least RM11 billion of 1MDB's debt if the company could not and ratings agency Fitch had also warned that the country's credit rating may be downgraded on account of 1MDB struggling to meet its debt obligations, among other reasons.

In concluding this litany of problems, Khairie Hisyam had this mentioned: "From where Malaysians are standing, these issues and more surrounding 1MDB sound far than small."

\subsection{Just a wrong business model. Period!}

First things first, what exactly is the $1 \mathrm{MDB}^{\prime}$ s business model? And related to this, what are its ramifications as far as the company's financial statements are concerned? The answers may be found in an excellent write up by Ben Shane Lim around mid January 2015 at a time when most Malaysians (and for that matter the rest of the world too) were still in the dark on the debilitating goings on in 1MDB (Lim, 2015):

In a nutshell, $1 \mathrm{MDB}$ appears to have borrowed a huge amount of money at too high a price to purchase overpriced assets that cannot cover the debts. Why this has happened is open to speculation. The net effect is that $1 \mathrm{MDB}$ has been relying on massive land revaluation gains to book accounting profits, but suffers from negative cash flows as whatever cash it has is used to service the debts. In the financial year ended March 31, 2014 (FY2014), it suffered a negative cash flow of RM2.25 billion. Ultimately, this business model doesn't appear sustainable, a fact that became more apparent when 1MDB posted a loss of RM665.3 million for FY2014, weighed down by RM2.4 billion in financing costs. This isn't particularly surprising, since 1MDB had relied on over RM2.74 billion in land revaluation to turn a profit in FY2013. But the losses have been a wake-up call for Najib's administration. (Emphasis added.)

But still there are opposing sides on the 1MDB's business model: two individuals - one from the then opposition and the other from the government side - had brought up its negative aspects; and, the third Arul Kanda Kandasamy the then president and group executive director of the 1MDB had seen nothing wrong with the $1 \mathrm{MDB}^{\prime}$ s business model. This he mentioned repeatedly in an interview which he gave to the newspaper The Edge in January 2016.

One from the first two was Parti Amanah Negara (Amanah) central committee member Dr. Dzulkefly Ahmad. As mentioned in a write up in the Malaysiakini in early January 2016 (Alyaa, 2016c):

"As the strategic arm of the government, they have done nothing spectacular. They survived due to asset valuation," said Dzulkefly. 1MDB, he said, survived solely because it was given "dirt cheap assets on a silver platter" which it in turn flipped "1,000 times". "Selling the assets to those who were willing to pay for that price. In the end 1MDB flipped it to foreigners. "What business model is this?" he 
questioned. Dzulkefly pointed out how 1 MDB had never brought real value proposition for the country.

As for the second person Dato Sri (later Tan Sri) Abdul Wahid Omar who was the then minister in the prime minister's department, he was reported to have said in an interview given to the US broadcaster the CNBC that the 1MDB model was unsustainable from the very beginning ("1MDB unsustainable from the start", 2016). Specifically, in a Malaysiakini news report that came out in early April 2016, he was quoted to have said in the CNBC interview: "The model that they took was low capitalisation and huge borrowings, and I think as they found out, it wasn't a sustainable model. With that came debt realisation, where the board has now embarked on a rationalisation plan."

Finally, Arul Kanda Kandasamy in an interview that he gave to The Edge and which was published in The Edge Malaysia Weekly in January 2016, he had mentioned early on that the 1MDB's business model was concerned with the use of debt to run its business and that it relied on asset sales to repay debt (Lim and Barrock, 2016). Not long after saying these and when he was specifically asked whether such was "the right business model", he had among others made the following claim:

To me, the use of debt is not wrong. In your day-to-day life, when you buy a house, it is debt funded. When you buy a car, very similar. Debt creates a certain discipline that you have to repay the debt and therefore run your business in a particular way. The use of debt in a government-owned company also frees up funds that would otherwise have to be injected as equity. It can be used for development projects and so on and so forth. A lot of firms use debt. Banks are a good example, they are highly leveraged entities. Where it becomes a concern is where the maturity of the debt and the cash flow of the company don't match. Even in that scenario, many development companies will tend to refinance debt so you don't necessarily anticipate until the project is finished. And if you look at $1 \mathrm{MDB}$, that is what happened. If you look through the financial statements over time, debts were taken, they were repaid, new debts were taken on, as the company grew and the business profile increased... [W] hat I am saying, the model to me is fine.

From the government side, aside from Arul Kanda Kandasamy who was positive about the 1MDB's business model, there was another person who on numerous occasions (while holding the post of the deputy finance minister and later the post of the second finance minister) appeared to have taken $1 \mathrm{MDB}^{\prime}$ 's business model in stride as one of the three causes for the 1MDB's problems - no more no less. In short, he behaved as if the 1MDB's inappropriate business model happened to be implemented without even an iota of ill intention from the concerned parties!

The latest remarks of his took place in April 2018 on the run-up to GE14 during an interview with The Edge and in regard to the question on "issues" that Malaysia had to deal with ("What about issues such as 1MDB and TRX...") where he asserted ("Run-Up to GE14", 2018): "Issues are issues. We learn from our mistakes, resolve the issues, go back to the three things I said - wrong business model, weak management and poor governance." (It is perhaps worth noting that this answer of his came following his answer on the affirmative for the question on whether Malaysia was doing all right economically "So, you are saying economically, Malaysia is doing all right? Are you concerned about the national debt?")

But really it was what he said the first time in Parliament in May 2016 that had let to some controversy. And what he said was reported by the Malaysiakini as follows (Chie, 2016a): 
The government has never claimed that 1 MDB was a good investment, said Deputy Finance Minister Johari Abdul Ghani. "The government has never said that," he told the Dewan Rakyat during question-and-answer session today. Wrong business model, weak management and poor governance were the three reasons that (contributed to) 1MDB's lack of competitiveness, he said. "1MDB relies on loans to run such a huge business and it was unable to gain profit in the short term; this is a mismatch or a wrong business model," he said. He added that these were highlighted in the Public Accounts Committee's (PAC) report on 1MDB.

And in his reaction to this remark, Tony Pua on the very next day in the Malaysiakini had written a stinging piece which had among others the following remark (Pua, 2016):

I am stunned to hear the normally intelligent (at least while he was a backbencher) Johari Abdul Ghani respond to questions in Parliament with regards to the monster scandal 1MDB. ... After years of gloating about $1 \mathrm{MDB}$, the new deputy finance minister has the cheek to come to Parliament to tell Malaysians that "the government never claimed that 1MDB was a good investment". If the government never believed that 1MDB "was a good investment", why didn't the government shut it down much earlier before it incurred up to RM55 billion of debt and became the single biggest financial scandal in the history of Malaysia? If Johari's assertion is really true, then the BN government must be the stupidest government in the whole world for sticking with the 1MDB investment despite knowing that it is not a good investment.

Also not to be forgotten at all was the revealing reaction coming from another parliamentarian Raja Kamarul Bahrin Shah Raja Ahmad that was published in the Malaysiakini on the very same day that Tony Pua had made known of his reaction as shown in the quotation above (Raja Kamarul Bahrin Shah, 2016):

On May 25, 2016, Deputy Finance Minister Johari Abdul Gani informed Parliament that 1MDB was based on a "wrong business model." He also said the government "never claimed it was a good investment". These were all facts the government should have known well before 1MDB started on the suicidal spiraling debt-accumulating misadventure. What is unforgivable and totally irresponsible is the fact the federal government had been well forewarned of the impending high failure risks by a state government that refused to mortgage its future away no matter how much arm twisting was applied. (Emphasis added.)

The state government referred to by Raja Kamarul Bahrin Shah was of course Terengganu's and Terengganu is also where he comes from. As he put it next:

History shows that Terengganu Investment Authority - TIA, was set up through the initiative of the federal government under Prime Minister Najib Abdul Razak as a sovereign fund vehicle. The intention was to pledge as collateral future earnings of Terengganu's oil and gas revenue with no other known assets or projects in hand. The government of Terengganu, which was then headed by Ahmad Said, realised it was a very high-risk concept which will compromise Terengganu's future. The unknown figure, a businessman by the name of Jho Low who appeared to be part of the scheme, caused further doubts in the minds of Terengganu's government. ... Eventually TIA became 1MDB, but even before any project was launched it was learnt some hundreds of millions was paid out as commissions to certain individuals. (Emphasis added.)

And as perhaps to be expected from anyone with more than enough common sense, Raja Kamarul Bahrin Shah had raised the obvious questions right after saying those earlier: 
The big question is, how is it the federal government with all the facilities and expertise at its disposal could not foresee the great risks that a small state government like Terengganu had the foresight and wisdom to avoid? Is it negligence, irresponsible attitude or pure greed that lead to the mess Malaysia is in today? These are questions being asked by Malaysians and the international community.

In the last few lines of his piece, Raja Kamarul Bahrin Shah went for the kill. He wrote:

1MDB was not based on a "wrong business model" as said by the deputy minister, but it was set up on a "known flawed business model" rejected by the government of Terengganu. The federal government had been warned about its unworkability by the state government. Everyone could see it is a highly risky model but the government decided to proceed and accumulated more than RM40 billion in debt. (Emphasis added.)

But several weeks after making the controversial remark in Parliament, the person Datuk (later Datuk Seri) Johari Abdul Ghani who by then had become the second finance minister appeared to have failed to learn his lessons. In a write up that came out in early July 2016 in the Malaysiakini and appeared to be based upon an interview he gave to the news portal, the following was mentioned among others (Chie, 2016b):

Newly-minted Finance Minister II Johari Abdul Ghani has made 1MDB one of his priorities, and pledged to resolve the state investment fund's problems transparently. ... He also promised that the government would address the issues raised in the Public Accounts Committee's (PAC) report on 1MDB. ... While he acknowledged 1MDB's problems were caused by wrong business model, weak management and poor governance, the businessman-turned-politician defended the need for a strategic fund.

Worse, he had also made a mind boggling statement which appeared to have never before been stated out by any party closely associated with the $1 \mathrm{MDB}$ and who would know the company better than anyone else - including the second finance minister himself: "'Likewise with 1MDB, the (government's) idea was to set up a strategic company to develop unutilised land. And, along the way we deviated from what it was supposed to be and it turned into an investment entity." And right after that quotation there was another revolting remark of his reported in the following manner: "Johari said a strategic investment was not necessarily profitable, citing the mass rapid transit (MRT) project as an example."

In August the following month, in a speech he delivered at the Cheras Umno division meeting, Johari had again placed the blame on 1MDB's business model. The news report by Malaysiakini had this mentioned (Alyaa, 2016b): "Earlier in speech, Johari also took the opportunity to reiterate the government's narrative that problems surrounding state-investor $1 \mathrm{MDB}$ was largely linked to its poor business model and overall bad governance." Also, when the concerned journalist Alyaa met him later where he was asked "... how he could detach Najib from 1MDB's poor decision making process...", this was his response: "I do not want to give (Petaling Jaya Utara) MP Tony Pua more ammunition. This is a democratic country and he can continue to say whatever he wants. No need to split hairs. At the end of the day we want to solve the problem...."

And finally in March 2017, Johari had again made the same arguments all over again - in an open letter to Tony Pua published in the Malaysiakini (Johari, 2017):

There is no clear-cut evidence to bring any criminal action against anybody for the 1MDB case at the moment. Otherwise, I am sure that the police, MACC, Bank Negara Malaysia, the auditor-general, 
the public accounts committee and the attorney-general would have taken action against the responsible individuals. The only conclusions that I can make from the PAC report are that 1MDB suffered from poor corporate governance, wrong business model and weak management.

Though hands down there are several serious problems with both the contents of the PAC report and the fact finding process taking place which had culminated with the issuance of the report (and these to some extent are covered in the PAC Report Cautionary Note below) to lead to the conclusion that it would be better to ignore all that which are found in the report, the following quotation (which had first appeared in Part I of the case study) coming from Tony Pua should still be worth noting for his uncompromising response to that very unbelievable remark from Johari (Murugiah, 2017b):

You supported your claim by saying the Auditor-General and the PAC could not point to anything specifically wrong with $1 \mathrm{MDB}$. Again, I pointed to specific sections of the PAC Report which clearly concluded that the 1MDB top management has on dozens of occasions - lied and misled the Board of Directors, defied the decisions of the Board or worse, acted without the Board's authority, all of which are legal offences. The PAC even asked the authorities to investigate the CEO, Datuk Shahrol Halmi and other officers involved for the above wrongdoings. However, a year later, Datuk Shahrol Halmi remains comfortably as of today, a Director of PEMANDU agency in the Prime Minister's Department. (Emphasis added.)

And it should also be worth noting that Tony Pua right after giving that succinct reply had made several devastating points against the concerned parties - but these are laid out later under the heading "No criminal doing". At this point, it can perhaps be surmised that the argument that the inappropriate business model was one of the root causes for the problems 1MDB was facing was certainly not surprising, for it allows certain parties who did not want to countenance the possibility of management fraud taking place in the company something to propagate on. As for some other parties who may be alleged to be the culprits over the dastardly acts taking place in 1MDB and related entities (and, if truth be told, over numerous other entities linked to the Malaysia's federal government for so many years until recent time), the $1 \mathrm{MDB}^{\prime}$ ' business model argument that they like to bandy around may be considered to be one of their tactics to keep others from getting to know the truth...

But, after all is said and done, there is in fact something crucial to be said regarding the 1MDB's business model - but it is not concerned with it being either the root cause or a symptom for the 1MDB's myriad of problems. Instead and to be more exact, the horrifying 1MDB's business model was no more and no less than a tool (like several others) to channel out billions of dollars of funds (coming in from one bond issuance after another) to certain parties from inside and outside the 1MDB from within and outside Malaysia for them to become multimillionaires or billionaires overnight able to spend it all on all that their hearts desired - without the slightest care as to what that would do to the long suffering Malaysians who toil day and night to earn a few miserable ringgits and for that matter to the country as a whole!

\subsection{Lapses in governance! Period!}

In delivering the opening speech at Invest Malaysia 2017 in Kuala Lumpur in July 2017, the then prime minister Najib Abdul Razak had admitted that there were certain things not right with the 1MDB - but this did not go to the extent of his pointing out that there was criminal intent behind it all. Instead, in his view there was malice indeed coming from the opposition coalition Pakatan Harapan which tried to use the 1MDB issues to bring down the government! As he put it (“Najib's full speech", 2017): 
At $1 \mathrm{MDB}$ it is now clear that there were lapses in governance... But let's not forget that while there were issues at $1 \mathrm{MDB}$, certain politicians blew them out of proportion, and tried to sabotage the company, in an attempt to topple the government in-between election cycles. At the time we knew the real issue was not $1 M D B$, and that if $1 M D B$ hadn't been around they would have chosen another line of attack to try to illegitimately change the government.

In a media statement issued on the very same day that the speech was delivered and which was published intact the next day at theedgemarkets.com, Tony Pua gave out quite a response ("Why has Najib refused", 2017). He began by saying:

For the local and foreign investors listening to the Prime Minister's speech when opening the InvestMalaysia 2017 conference, it must have been an utterly surreal experience. While he acknowledged that there "were lapses in 1MDB's governance", and he had "personally given instructions for a rationalisation of the company's operations", he denied culpability and even blamed the Opposition for fanning the flames.

Next, Tony Pua mentioned:

... the opening of the mid-year Parliamentary sitting this week saw more than 30 questions thrown out for utterly bizarre and frivolous reasons. My question on the current value of the 1MDB "units" investment and who is the custodian bank was rejected because they apparently contained questionable assumptions ("sangkaan") and were a figment of my imagination ("buah fikiran"). My question on whether the Attorney-General had investigated the claims made in the latest United States Department of Justice (US DOJ) suit to seize up to US\$1.7 billion worth of launder assets from 1MDB funds was similarly and incomprehensibly rejected because it was deemed a "sangkaan". I had a total of 5 questions relating to $1 \mathrm{MDB}$ which were rejected.

And how would all that be connected to Najib's remark above at the conference? As Tony Pua put it:

The investors on the floor would have loved an opportunity to ask the Prime Minister, if he had indeed done no wrong, why would he not just give simple answers to the simple questions above? In fact, Malaysians would also like to know why Dato' Seri Najib Razak only has the courage to deliver his "defence" of 1MDB with a straight face to an audience without a opportunity to raise questions, and refused over the past 5 years to address the Parliament? In fact, the Prime Minister would have had the best opportunity to make the Opposition look like complete idiots if it were true that the latter was blowing the issue "out of proportion".

And in the final four lines of the media statement, Tony Pua went for the kill! He pointed out:

Let us make it clear that the Opposition did not sabotage 1MDB. The Prime Minister and the 1MDB top management did the sabotaging by carrying out misappropriations exceeding US\$5.7 billion (RM25 billion) resulting in the company failing to meet its debt obligations. However, we are in agreement with the Prime Minister that we are indeed fanning the single largest financial scandal in the history of Malaysia. This is in order to topple his disgraced administration, which has become a renown kleptocracy in the eyes of the world. The investment community are not gullible fools who would believe the naked emperor. Their confidence in the country will only be returned when a new clean and competent government gets elected by 2018. (Emphasis added.)

In a nutshell perhaps it is not at all surprising what the then prime minister had said regarding the 1MDB in his speech at the Invest Malaysia 2017. After all, as far as the 1MDB saga is concerned, it appears that just about every remark of his to this very day (when he is no longer the country's prime minister) has 
been pretty much lacking in synchronicity with all of the company's dire news and development on the ground! In short, it is as if he is living in an alternative universe... And the evidence of such may be found in a sample of news reports found in theedgemarkets.com and which dated within a period of just over a year from April 2015 to May 2016 whose headings are listed next:

- $\quad 1 M D B$ is not bankrupt, says PM Najib (April 8, 2015)

- 1 MDB RM42 billion now part of TRX, Bandar Malaysia land bank, says Najib (May 18, 2015)

- Stick with me on 1 MDB or resign, Najib tells ministers (June 1, 2015)

- I want answers on 1MDB too, but action must be based on facts, says Najib (June 9, 2015)

- Malaysia's Najib says "conscience clear" as funding scandal festers (December 8, 2015)

- PM Najib : 1MDB's 'real legacy' seen in TRX, Bandar Malaysia (April 12, 2016)

- Najib: 1MDB's problems due to failure to issue IPO (May 11, 2016)

Four of those listed have their relevant parts reproduced next:

- 1MDB RM42 billion now part of TRX, Bandar Malaysia land bank, says Najib (May 18, 2015). (Muzliza, 2015)

Prime Minister Datuk Seri Najib Razak today insisted that state fund 1Malaysia Development Bhd's (1MDB) RM42 billion was not lost, saying that the money was now part of the Tun Razak Exchange (TRX) and Bandar Malaysia land bank. Najib, in trying to put the controversy surrounding 1MDB to rest, said if he was rich, he would have bought the land in the two areas. "The RM42 billion is not lost. There, the 70 acres TRX and 500 acres Bandar Malaysia lands," said Najib, in front of hundreds of Umno Selangor members in Klang today. "If I am a rich man, I would buy a land at the prime area because I know the value (of the land) in 20 years," he added. Najib was responding to critics the likes of former prime minister Tun Dr Mahathir Mohamad demanding answers on the fund and explanation of the whereabouts of the RM42 billion debt racked up by 1MDB.

- Malaysia's Najib says "conscience clear" as funding scandal festers (December 08, 2015). ("Malaysia's Najib says "conscience clear", 2015)

Malaysian Prime Minister Najib Razak said he had done nothing wrong in receiving hundreds of millions of dollars into his personal bank accounts, as his party opened its annual meeting on Tuesday amid tensions over a festering funding scandal. Najib has so far weathered calls for him to quit over allegations of graft at state fund 1Malaysia Development Berhad (1MDB) and his receipt of 2.6 billion ringgit (\$610.8 million) in what he says was a political donation. But pressure is mounting on Najib as the saga causes a rift between top leaders in his United Malays National Organisation (UMNO)... In his most detailed explanation since the scandal erupted in July, Najib said his conscience was "absolutely clear" and the truth would come out when investigations were completed. ... The Wall Street Journal had reported in July that the funds had been discovered in Najib's accounts by investigators probing accusations of financial irregularities at 1MDB. Najib, who chairs 1MDB's advisory board, has denied the money came from the fund, which is being investigated by several foreign agencies, including the FBI. 
INTERNATIONAL JOURNAL OF ACADEMIC RESEARCH IN BUSINESS AND SOCIAL SCIENCES

Vol. 9, No. 3, March, 2019, E-ISSN: 222 2-6990 @ 2019 HRMARS

- PM Najib: 1MDB's 'real legacy' seen in TRX, Bandar Malaysia (April 12, 2016). (Ahmad Naqib, 2016a)

In his keynote address at Invest Malaysia 2016 today, Najib said TRX and Bandar Malaysia would become vibrant new centres. ... "In the years to come, they will be the real legacy of 1MDB. They will be what [are] remembered. And history will show that the shameful politically-motivated allegations made to unseat a democratically-elected government were false," said Najib. ... Najib reiterated that lessons must be learned from 1MDB's weaknesses, which were outlined in the Public Accounts Committee (PAC) report. Action would be taken if any evidence of wrongdoing was found, he added. He said there would be accountability for $1 \mathrm{MDB}$ as the success of government-linked corporations and consistent economic growth would not be possible without accountability. "The report also shows that the allegations of RM42 billion going missing, as some claimed, are completely false. Malaysia's name has been unfairly dragged through the mud," Najib said.

- Najib: 1MDB's problems due to failure to issue IPO (May 11, 2016). ("Najib: 1MDB's problems", 2016)

Prime Minister Datuk Seri Najib Razak has blamed a failed initial public offering (IPO) exercise, as a result of being "attacked", as the main reason why 1 Malaysia Development Bhd (1MDB) encountered problems, according to a Bernama report. Bernama quoted Najib as saying that 1MDB used the debt funding approach to operate its business, which required an IPO to be undertaken in the shortest possible time. "At the time, we tried different approaches as we did not want to utilise government funds. Government funds can be used for other projects or programmes. "For 1MDB, we utilised 'debt funding' on condition that we will undertake an IPO very soon. Yet, we did not foresee that 1MDB would come under relentless 'attacks'," Najib said in an exclusive interview telecast live over TV1 last night in conjunction with Umno's 70th anniversary. "When the 'attacks' were mounted, the IPO exercise could not be carried out, hence the cash flow problems," Najib said in the report. The prime minister was also reported as saying that a report on 1 MDB was submitted to the Public Accounts Committee (PAC) to establish if there were any irregularities or wrongdoings, on his part, in the company. "PAC has presented its findings. PAC deputy chairman Dr Tan Seng Giaw, an opposition party member, made a public statement and opined that I did nothing wrong in 1MDB. "I consider the 1MDB issue as a business problem ... (perhaps) its business model was not so suitable, its gearing was very high," he said, adding that this was turned into a political issue by certain quarters who used it to try to topple him.

\subsection{No criminal doing. Understood?}

The argument that the ugly goings on in 1MDB over the years was devoid of sinister intentions come from various personalities directly and indirectly associated with the company. The discerning readers could have easily detected this from what is delineated above. And of course there exist other instances. Two are delineated. One is concerned with what took place in March 2017 in the going back and forth between Tony Pua and Datuk Seri Johari Abdul Ghani. Readers are reminded that certain parts of this going back and forth were already mentioned earlier - one in Part I and another above. The other is concerned with the various remarks made by the 1MDB's Arul Kanda Kandasamy over three different 
time periods: January 2015; January 2016; and, the second quarter of 2016. The ones he made in the second quarter of 2016 appeared to be the direct opposite of those in January 2015 and January 2016. Following the delineation of Tony Pua - Johari back and forth and Arul's remarks over time, there is a part devoted to the effort to understand what appears to be the inconsistent stance by Arul over time. Readers are warned that this very last part can be mind boggling to say the least...

\subsubsection{Tony-Johari's March 2017 back and forth}

It began at a luncheon talk organized by the Malaysian Industrial Development Finance Bhd (MIDF) in mid March 2017. In regard "... to a question on the perceived lack of effort from the local authorities in investigating $1 \mathrm{MDB}$, as compared with several prosecutions and convictions in Singapore related to the state fund", the second finance minister Johari was reported to have mentioned that "...whatever has been made public about $1 \mathrm{MDB}$ is only half the story and that a full picture is needed before any charges are made..." (“Johari: We can't press charges”, 2017). He was also quoted to say: "Even the PAC (Public Accounts Committee) and AG (auditor-general) were unable to specifically tell what went wrong. The transfer of the money to the accounts and so on, it's not that. That's only half the story. If you want to charge people, you need the complete story."

In response to this and other remarks, Tony Pua a few days later had said that Johari must prove that the Auditor-General (AG) couldn't find specifically what went wrong with 1MDB by seeking declassification of the AG's Report on 1MDB (Murugiah, 2017a). Also, in the very same news report, Tony Pua was quoted to say: "Datuk Seri Johari must prove to Malaysians that he has not become a big liar defending a kleptocratic administration by demanding that the Cabinet declassify the Auditor-General's Report immediately." Next, Tony Pua raised the question: "Can Datuk Seri Johari tell us why the AG's Report remains classified? Is it because even the 'sanitised' PAC Report itself has hinted at a whole lot of shenanigans discovered by the AG, if further exposed, would make life difficult for the Barisan Nasional Government?" Following the raising of these questions, the news report had this mentioned:

The Opposition lawmaker said that for example, the PAC found that the 1MDB's multi-billion dollar investments in Petrosaudi and other funds were carried out without any proper study or due diligence. "For that matter, the PAC and the AG found that 1MDB decided to invest a total of US\$1 billion in a joint venture with Petrosaudi International Limited within just 8 days. "We have also since discovered with corroborating evidence from Bank Negara as well as court cases in the United States and Singapore, that US\$700 million of that sum was siphoned to Good Star Limited, a company owned by the flamboyant Jho Low," he said. Pua said the PAC and the AG also found that 1MDB's management executed multiple multi-billion dollar transactions without the approval of the 1MDB Board of Directors. "The PAC and AG also concluded that the top management had provided false information to the Board of Directors on multiple occasions. Worse, the top management was found to have acted in defiance of decisions made by the Board of Directors. "The PAC and AG's Reports were very specific in these allegations," he said.

With these raised, Tony Pua surmised that "... there were already sufficient instances of criminal wrongdoings and negligence by the top management highlighted by both the AG and the PAC in their reports." Next, he stressed: "This was also the reason why the PAC had recommended that the authorities carry out investigations against Datuk Shahrol Halmi and other management officers who were involved." And right after that, Tony Pua had blasted out a number of penetrating questions: 
Hence the question that the Second Finance Minister must answer is - why haven't investigations into the shenanigans in $1 \mathrm{MDB}$, especially by Datuk Shahrol Halmi been completed after more than a year? Why is Datuk Shahrol still a Director at the PEMANDU agency in the Prime Minister's Department? Is it because he is 'untouchable' and protected by the Prime Minister himself, so as to avoid even more damning truths surfacing on how tens of billions of ringgit were misappropriated by $1 \mathrm{MDB}$, of which a substantial portion of it was channelled to Datuk Seri Najib Razak?

On the very same day that all this strong words coming from Tony Pua could be read by all and sundry, Johari come out with a response which was published in the Malaysiakini. It is notable that the original piece which came out in the early afternoon was later updated just before night fall. In the twelveparagraph response, Johari had begun with the following remark (Johari, 2017): "Tony Pua has of late accused me of many things, being a liar, for one thing and now in his FB page, he accused me of covering up for the prime minister and also that I was trying to pull a fast one over the rakyat on the 1MDB issue." Not too long later Johari put forth the following argument:

The 1MDB issue has been extensively deliberated by all parties... Never before have I seen or experienced anything resembling the effort or the interest put into dissecting and scrutinising 1MDB, not only by us Malaysians but also by the United States, Switzerland, Singapore and other financial centres of the world. Despite all these, we still do not have a "complete picture" of what happened to $1 \mathrm{MDB}$ and why, until today, none of these jurisdictions have taken specific charge against 1MDB or its employees on the criminal aspect of the case. Even the actions taken by the Singapore government were only in respect of the non-compliance of their banking laws.

Next, he pointed out:

Even the United States' Department of Justice (DOJ) couldn't come up with any solid proof to prosecute any individual on criminal charges in relation to 1MDB. What the DOJ did was to freeze assets allegedly belonging to certain individuals connected to 1MDB in the hope that by freezing the assets, the owners will come forward and disclose to the DOJ how the massive assets could be accumulated without going through the US' stringent protective laws.

And right after saying all that, Johari made the following claim: "As far as the government is concerned, there is nothing to hide and nothing to cover up. The fact is that, and I know Pua being a PAC member knows it himself. There is no clear-cut evidence to bring any criminal action against anybody for the 1MDB case at the moment." He also said, and this was pointed out above under the heading "Just the business model", that as far as he was concerned "[ $t$ ]he only conclusions that I can make from the PAC report are that $1 \mathrm{MDB}$ suffered from poor corporate governance, wrong business model and weak management."

Note that in the latter part of the letter Johari had among others mentioned a couple of remarks which were nothing short of mind boggling in nature. One, he mentioned: "You were a member of the PAC and even you know that the PAC could not recommend the charging of any particular individual for criminal conduct in the 1MDB case due to lack of evidence." Another in the second to the last paragraph of his open letter, he attempted to patronize Tony Pua by saying:

Pua, you need to realise by now that you are foremost, a lawmaker, a Member of Parliament. You cannot continue to be a judge, jury or executioner or all of them in one. Though I am a junior in comparison to your tenure as MP, your behaviour in respect of the entire affair does not fit that of a lawmaker. The spectacle of name-calling, not only towards me but towards other members of the 
administration as well, is nothing less than embarrassing and demeaning to your standing as a Member of Parliament. Give it a rest. I am sure that the folks of Petaling Jaya Utara elected you as their MP to do better things than just being obsessed with 1MDB.

With letter of such revolting contents around, it was perhaps to be expected that Tony Pua had in turn gone ballistic! In a write up in theedgemarkets.com quite early in the morning the next day, its first half had among others the following (Murugiah, 2017b):

In an open letter to Johari today, Pua, who is DAP national publicity secretary and MP for Petaling Jaya Utara said that he stood by his accusation that the former was "covering up for the Prime Minister". ... He said that Johari in an open letter to him had written that "as far as the government is concerned, there is nothing to hide and nothing to cover up." "Then, I ask you, if so, why do you not propose for the Cabinet refusing to declassify the 'harmless' Auditor-General's Report? "However, instead of answering all of the above questions, you ask me to "give it a rest"," he told Johari.

As for the second half, after saying that "... there was a difference between 'serving the nation' and 'serving the Prime Minister'," Tony Pua had raised some very penetrating questions. These are:

Do you not realise that we are now a renown kleptocracy and how damaging that is for our country? Everyone who has taken an interest in the affairs of Malaysia knows from the documents presented by the United States Department of Justice and the Singapore Courts that US\$731 million from $1 \mathrm{MDB}$, found its way through dodgy investment funds and deceptive offshore companies into the personal bank account of Dato' Seri Najib Razak.

Do you not think that to "serve the nation", we must work to revive our heavily-tarnished global reputation? And do you not think that the only way we can remove the kleptocracy label from Malaysia is not by sweeping the truth under the carpet but instead ensure that the kleptocrats are charged and appropriately punished?

In fact, if you really want to take "positive and proactive steps" to help the nation, why haven't you made a claim for the US\$1 billion worth of assets being seized by the United States which were acquired with funds laundered and stolen from $1 \mathrm{MDB}$ ? Why is the Government still keeping up the pretences that $1 \mathrm{MDB}$ did not lose these billions of dollars?

Next, in the second last paragraph of the news report, Tony Pua's conclusions following all that he mentioned earlier came out crystal clear: "Pua said the 1MDB issue does not deserve to be rested because Johari and his fellow Ministers had refused to answer simple questions and more importantly, the crooks who allegedly misappropriated more than US\$5 billion are still at large." And related to this Tony Pua was quoted to say: "Any elected representative with any sense of morality and integrity, who believes in protecting the interest of the man-on-the-street and who wants justice meted out to criminals who rob the country will never let the matter rest until the truth is found."

\subsubsection{Arul's remarks over time...}

Was it true that Arul's remarks made in the second quarter of 2016 were not consistent with those made in January 2015 and January 2016? The author humbly thinks so. But the readers are free to decide otherwise. 
January 2015 email reply. The heading for the news report published in The Edge Financial Daily in the middle of January 2015 provided the picture that it was concerned with the SRC International which was for some years a subsidiary to the $1 \mathrm{MDB}$ but the truth is that almost every single line in the second half of the write up was concerned with $1 \mathrm{MDB}$. And it all began with the following appearing in the middle of the write up ( $\mathrm{Ng}, 2015)$ :

1MDB has come under fire from Rafizi and other opposition politicians as well as influential former prime minister Tun Dr Mahathir Mohamad over the fund's heavy debts, its use of money and its opaque operations. ... Penang Umno leader Datuk Seri Khairuddin Abu Hassan also lodged a police report late last year against the company over its alleged dubious financial activities and massive borrowings.

And right after all that:

However, the company's newly appointed group executive director Arul Kanda told The Malaysian Insider that the string of attacks were mostly politically driven and not "grounded in reality". The high-flying banker said it was quite clear most of the allegations directed at the company were driven more by politics, rather than genuine business considerations. Without naming them, Arul said "certain individuals" who were not privy to the company's operations, and who do not have the full facts or understand the context of decisions made by $1 M D B$, have been at the forefront of these attacks.

Following this the news report had quoted verbatim the remarks that Arul made in his "email reply to The Malaysian Insider last week":

I've stated this before but, as a banker, I take due diligence very seriously. As such, when considering whether to take on this role, I examined every piece of information I could find about $1 \mathrm{MDB}$, including numerous media reports concerning allegations directed at the company. Subsequently, I had the opportunity to hold in-depth discussions with the board, and I have personally looked into the background of the issues covered by these allegations as well. On the back of this, what I can tell you is that while there are certainly some challenges that we will need to - and can - overcome, the majority of the allegations directed at the company have no grounding in reality.

Arul's January 2016 interview. The January 2016's interview was the second which Arul Kanda Kandasamy gave to The Edge following the first one a year earlier when he first came to the job as 1MDB president and group executive director. And it is notable that in the last one third of the interview when he was questioned on the need for some people who were responsible for 1MDB to be made accountable he answered (Lim and Barrock, 2016):

If you listen to what the opposition is saying, or what some of The Edge headlines implied, there is criminal wrongdoing. But criminal wrongdoing requires certain elements. These were business decisions, taken via the governance process, which the management proposed and planned. There were independent advisers advising to it. The board then reviewed and gave its consent, and in certain cases, the shareholder approved. Making a business decision, provided you don't have those elements of criminal wrongdoing, clearly, this cannot be a criminal offence... If a business decision doesn't go according to plan, it doesn't necessarily translate into criminal sanctions.

Following that remark and for the following question "[s]ince (you insist) there was no wrongdoing, the board and the management will be all right?", Arul had mentioned among others: 
I won't comment on that. There may or may not be wrongdoing. I am not absolving anyone. What I am saying is that the challenges in $1 \mathrm{MDB}$ are business challenges. The only reason people feel so strongly about the issue compared with other businesses that have run into challenges is that the $1 \mathrm{MDB}$ has been used as a political issue to gain political mileage. And by doing that, passions were inflamed, soundbites were used, misleading statements were highlighted. But in business, sometimes things work out and sometimes they don't. But that's a fact. Otherwise, we'd all be billionaires today. There are challenges. That doesn't mean there is a crime.

As for his view regarding those who claimed "... that the Malaysian public is paying a steep price for 1MDB's mistakes as the money raised from the sale of assets could have gone to the national coffers", he had among others said:

Speaking of critics, there is a famous quote, 'A critic is someone who never actually goes to the battle, but who comes out after everything is done and shoots the wounded'. So, I take a very different view. As a Malaysian with certain skill sets and abilities, I want to be part of the solution and not part of the problem. History has many examples of companies that were set up and didn't quite achieve their objectives. 1MDB is no different in that case. ... If you look at it with a keen eye and the facts, a lot of these criticisms, they are not only misplaced but downright wrong.

Related to this and for the following question in the interview regarding the then federal government viewed by the Malaysian people to have been bailing out the 1MDB, he argued: "But in Malaysia, the chorus of misunderstanding and misperception is so strong, fuelled by newspapers like The Edge. Let's be frank, this caused a backlash against what would have been a perfectly normal and reasonable business decision." And finally in the second last question for the interview when he was asked point blank on the presence of wrongdoing in $1 \mathrm{MDB}$, he said: "I do not see any criminal wrongdoing. Of course, all of us have an opinion. You should have done this, or that. But this is normal. This is what happens." All in all, it is safe to say that all that he said in the January 2016 interview with The Edge were consistence with what he wrote a year earlier in an email that he sent as disclosed above to the news portal The Malaysian Insider when he had just been appointed to his job in the 1MDB - but such consistency appeared to be hard to find when comparison is made with what he mentioned just a few months later in April 2016 in another interview.

Arul's April 2016 brouhaha. On the very last day of March 2016 in the Singapore's Business Times there was a write up that was concerned with an interview that Arul gave the day before and where the following was mentioned (“'My job is done'”, 2016): "1MDB, whose advisory board is headed by Mr $\mathrm{Najib}$, has consistently denied wrongdoing. Kanda echoes statements by Mr Najib and other government officials that the allegations are unfounded and politically motivated." And there was next the quote coming from Arul who said: "The misunderstandings about 1MDB stem from the fact that what was a business problem became politicised and became a tool by the opposition or those not aligned with the government to topple a democratically-elected prime minister and government. That's the reality of it." But almost two weeks later in the second week of April the top few lines in a news report in theedgemarkets.com had screamed out the following (Lakshana, 2016b):

1 Malaysia Development Bhd (1MDB) said recent statements by Abu Dhabi sovereign fund International Petroleum Investment Corp (IPIC) and the Office of the Attorney-General of Switzerland (OAG) indicate that 1 MDB could be a victim of fraud. "1MDB is exploring all avenues open to us," 
said 1MDB president and chief executive Arul Kanda Kandasamy. "Further announcements will be made in due course."

Subsequently, The Edge Malaysia Weekly had published a piece comprising of an interview with Arul (Barrock and Fong, 2016). (Note that even though the piece referred to is dated some time in the second week of May 2016, it had first appeared in the same newspaper in the very last week of April 2016. This is as noted in the very first line of the write up: "This article first appeared in Corporate, The Edge Malaysia Weekly, on April 25 - May 1, 2016.) In the middle of the interview, he said: "What we cannot discount is there could actually be fraud, it could actually be a massive fraud that Khadem Al Qubaisi and Mohamed Badawy Al Husseiny did without anyone else knowing, and maybe there was collaboration [in the fraud] from our side. We have to be open to that fact." (Emphasis added.) And later on during the last part of the interview, he elaborated on what he said in the earlier part of the interview regarding the fraud possibility:

The fraud part I was referring to is the Swiss AG (Attorney-General) who said there is a possibility of fraud. I need to look at all possibilities, so my best-case scenario is, it is a corporate liability of IPIC and Aabar... Another possibility is fraud by the two - Mohamed Badawy Al Husseiny and Khadem Al Qubaisi. If that is established, then we have to trace what happened. Until I establish the first, I will not move to the second. Then, the third and worst-case scenario is if it was fraud with collaboration from this side - Malaysia. (Emphasis added.)

All that notwithstanding and presumably subsequent to the interview, within the very last week of April 2016 too in theedgemarkets.com the following was reported (Ahmad Naqib, 2016b): "Troubled strategic investment fund 1Malaysia Development Bhd's (1MDB) president and group executive director Arul Kanda Kandasamy said in a statement yesterday that he "had never admitted there was fraud" in relation to 1MDB." Next, Arul was quoted to say:

I refer to various [commentaries] on my recent statements regarding the possibility of fraud in relation to $1 \mathrm{MDB}$. In particular, I must clarify that I had never 'admitted there was fraud' as has been mistakenly alleged by various personalities and subsequently wrongly reported by certain media. What I did say is that, given the content of the April 12, 2016 statement by the Office of the Attorney General of Switzerland, 1MDB must now be open to the possibility of fraud, i.e. that it cannot be discounted. It is regrettable that various personalities have chosen to 'spin' my words to further their own agendas.

And guess what was all this concerned with? Well, to cut a long story short, it is about the USD3.5 billion payment 1MDB made to the "fake" Aabar BVI. Specifically, prior to 1MDB's remarks in the second week of April 2016 quoted above, the Abu Dhabi-based International Petroleum Investment Company (IPIC) and Aabar Investments PJS had declared that they had no link whatsoever with a British Virgin Islandsincorporated firm dubbed Aabar Investments PJS Limited (Aabar BVI) which had received 1MDB's US\$3.5 billion as a form of indemnity to guarantee a US\$3.5 billion bonds issued by 1MDB.

Also note that all that which Arul mentioned in the last few days of April had resulted with quick responses coming from several parties. Three of them are mentioned here. First, from Sarawak Report, the following was among others mentioned (in a blog post which believe it or not dated several days prior to the publication of the interview in the last week of April 2016) (Sarawak Report, 2016): 
After a year of trenchant denials and counter-accusations, he also accepts there "could have been" a massive, multi-billion dollar fraud after all (but, we note, no apologies to Sarawak Report and others). What's more, he even concedes, "maybe there was collaboration" in this fraud from within $1 M D B$ itself...... it really is time for you to run, Shahrol Halmi, the world can see the red dot in the centre of your forehead.

As for Lim Kit Siang from the political party DAP, in the Malaysiakini, he had mentioned a mouthful of penetrating stuff! Among others as reported in the news portal (“Come clean", 2016):

DAP veteran Lim Kit Siang has urged 1MDB president and executive director Arul Kanda Kandasamy to come clean and own up to all allegations of financial mismanagement, including decisions made before his time. This, he said, would be the only way for Arul Kanda to earn some public sympathy. ... Lim, however, stressed it was not sufficient for Arul Kanda to merely distance himself from the allegations, after numerous exposes by the international media and whistle-blower website Sarawak Report. ... Lim pointed out that even though some of the decisions were made before Arul Kanda assumed his post in January last year, he had defended their propriety and correctness for more than a year, including in his appearances before the Public Accounts Committee (PAC) inquiry into 1MDB. Also, Lim was quoted to ask the following two questions: "Didn't Arul Kanda take the most elementary measures to check on the veracity of these detailed reports in the international media and Sarawak Report? Even more important and relevant, why did he defend the integrity and good governance practices of $1 \mathrm{MDB}$ in these cases of 'massive frauds' and 'collaboration'?"

Perhaps the most critical views came from Kee Thuan Chye who in his opinion piece in the Malaysiakini mentioned early on that Arul had now "... openly admitted that 1MDB might have been massively defrauded. More, he has also declared in an interview with The Edge Financial Weekly that "maybe there was collaboration from our side" (Chye, 2016). Next, Kee Thuan Chye proffered the following:

Maybe? He was supposed to investigate and find out for sure. How could he say "maybe"? We are talking about billions of US dollars going astray, and he says "maybe"? Has he failed in his job? Or has he succeeded exceedingly well by way of not exposing fraud when he discovered it? And is he still equivocating by saying "maybe" when he could actually mean "certainly"? Hiding the fraud would of course make him an accessory after the fact. And when it comes to prosecuting the culprits, he should also be implicated.

Next, Kee Thuan Chye had brilliantly narrated three separate cases where Arul's integrity was opened to question. For one of these three, he wrote: "Even more telling is the refusal of 1MDB under Arul's watch to provide details of the company's foreign banking transactions to the PAC and the auditor-general. Such information is crucial in determining, for example, whether a US\$700 million transfer made by $1 \mathrm{MDB}$ to an account belonging to Good Star Ltd was legitimate." As for the subject matter on hand which is the billions of dollars of payments totalling at least US\$3.51 billion made to British Virgin Islands registered company Aabar Investments PJS Limited, Kee Thuan Chye revealed:

According to the PAC report, $1 \mathrm{MDB}$ has not clarified whether this company was linked to the Abu Dhabi-registered Aabar Investments PJS that is a subsidiary of International Petroleum Investment Corp (IPIC), which actually declared to the London Stock Exchange this month that the Virgin Islands Aabar "was not an entity" within IPIC or Aabar Investments PJS. If the Virgin Islands Aabar is not a company that $1 \mathrm{MDB}$ had legitimate business dealings with, then it is incumbent on Arul to provide 
the essential information to set the record straight. Why hasn't he done it? Why did he not furnish the PAC with the required foreign banking information? What is he trying to hide?

Next, Kee Thuan Chye pointed out: "I could cite more instances of Arul's seemingly dodgy behaviour in divulging information to the public and the authorities, but I think the main points have already been clearly made." And in the latter part of his opinion piece, Kee Thuan Chye had raised a number of interesting questions - all were concerned with the fact that Arul had now admitted that there was the possibility of fraud perpetrated in the $1 \mathrm{MDB}$ :

Should he merely confine his stint at $1 \mathrm{MDB}$ to just the brief he was originally given when he now suspects that fraud has been committed? Isn't in the interest of 1MDB to get down to the bottom of the fraud? In fact, since 1MDB is government-owned, isn't it in the interest of Malaysian taxpayers to know the truth? And since all Malaysians pay tax these days, at least in the form of the goods and services tax (GST), doesn't this mean that all Malaysians have a stake in 1MDB and what it's been doing (or misdoing)? So, is Arul Kanda going to carry out his duty to all Malaysians or is he going to wash his hands of the matter? Is he going to care for the financial well-being of the country or uphold the interests of his master?

Right after raising that very last question, Kee Thuan Chye had among others mentioned the following: The answer to that has become more pressing this week in light of IPIC's termination of the deal to slash US\$3.5 billion of 1MDB's debts that has led to 1MDB defaulting on its payment of US\$50 million interest for bonds it issued. This latest development has prompted Pua to warn that as a result of it, "Malaysians need to brace themselves for the bailout of the century of at least RM20 billion by the Malaysian government". If that should turn out to be true, the culprits that started this whole 1MDB mess must be held accountable. Arul's head should also roll if he was not duly diligent in averting a disaster by coming clean with the company's dirt.

\subsubsection{Towards understanding Arul...}

Some may argue that all along from the very beginning when he was brought into 1MDB Arul was just pretending to be this and that to hide his actual role in assisting the alleged 1MDB culprits to escape punishment. Hence, on the very next day following the announcement made by IPIC on April 11, 2016 in London that IPIC and the true Aabar had nothing to do with the fake Aabar to whom payments were made by $1 \mathrm{MDB}$, theedgemarkets.com had this mentioned early on (Fui, 2016a):

DAP demands that the Royal Malaysian Police act immediately to investigate and arrest all parties allegedly involved in the massive scam involving at least US\$3.51 billion of payment to British Virgin Islands-registered Aabar Investment PJS Ltd (Aabar BVI) which is completely unrelated to International Petroleum Investment Corp (IPIC). DAP national publicity secretary Tony Pua said that the House of Cards started to collapse following the revelation by Abu Dhabi's state-owned IPIC that it nor its unit Aabar Investment PJS have any links to the Aabar BVI.

Next, Tony Pua was quoted to say: "This is a shocking announcement because it has finally confirmed what critics of $1 \mathrm{MDB}$ has suspected all along, that 1MDB has been making billions of dollar of payments to a fictitious Aabar BVI, pretending that it was payments to the real Aabar of Abu Dhabi." And such pretension as far as Tony Pua was concerned was most probable for two reasons: first, the PAC report tabled in the Parliament a few days earlier had disclosed that the auditor-general was unable to verify various payments made to Aabar BVI; and, second, the Auditor General had lamented that 1MDB had 
failed to provide not only any bank statements of its foreign bank accounts but also any documentary evidence of who were the owners of the fake Aabar BVI! Related to the latter, Tony Pua was quoted to say: "It is clear now that $1 \mathrm{MDB}$ was never able to provide the proof of ownership of Aabar BVI, because Aabar BVI is clearly a fake entity created to siphon the US\$3.51 billion or more from 1MDB." And pray tell the parties benefiting from the siphoning act? As mentioned in the news report:

Meanwhile, Pua also highlighted the report by the Wall Street Journal earlier alleging that Datuk Seri Najib Razak had received US\$681 million from Aabar BVI via intermediaries, which the Prime Minister claimed was a donation. In addition, the Wall Street Journal also alleged that Red Granite Pictures, which produced The Wolf of Wall Street, received US\$155 million of funding, directly and indirectly from Aabar BVI, Pua added.

As for the role played by Arul to have made all this and more shameless acts be kept under the carpet as long as possible, the very same news report (after having quoted Tony Pua who said that it was only now that the 1MDB had finally admitted to the misappropriation even though the matter was first exposed by the Wall Street Journal in November the previous year) had this to say within its last one third: "Despite repeated questions by the global media and critics like himself, Pua said the president of 1MDB, Arul Kanda Kandasamy, had stubbornly refused to address the question of who really owns Aabar BVI." And Tony Pua was quoted next for his explanation as to why Arul did that and what it all meant from now onwards:

Instead, he chose to repeatedly recycle the allegations that we are part of a global malicious conspiracy aiming to discredit 1MDB and the Malaysian Government. Arul Kanda's refusal to provide a straight answer to earlier questions only goes to prove that he was fully aware that 1MDB had signed agreements and paid billions of dollars to a fake Aabar BVI which was completely unrelated to IPIC. It also means that Arul Kanda and IMDB have deceived the AG and the PAC by their failure to disclose and explain the truth during the investigations... Malaysians have had enough of lies from Arul Kanda and 1MDB. We demand that the Royal Malaysian Police act immediately to investigate and arrest all parties involved in this massive scam... (Emphasis added.)

Since Arul was certainly not the only party of concern over what had happened, what did all this mean for the big picture comprising parties in and outside of the 1MDB other than Arul? As Tony Pua put it:

Hence it is crystal clear that there are parties in 1MDB who have acted in cahoots with IPIC's former top officials to scam Malaysians of billions of dollar. 1MDB had borrowed US\$3.5 billion with the guarantee provided by IPIC for the purpose of acquiring power companies in Malaysia. However, the entire sum and more have been clearly embezzled to an entity, Aabar Investment PJS Ltd, whose real beneficial ownership remains a mystery till today. (Emphasis added.)

Now, if all that has still failed to convince some people as to the apparent questionable side of Arul, note that the following day there was a bombshell of a news report whereby Tony Pua was said to have released a press statement accusing Arul that the latter had covered up the so called 1MDB-Aabar BVI scam. As mentioned in the news report (Lakshana, 2016c):

Pua said according to the Hansard of the PAC's 1MDB proceedings, he had asked Arul Kanda on Dec 18, 2015: "Is it true the allegations that the payment was made to an Aabar Investments PJS Ltd which was set up in perhaps BVI or Seychelles, which is unrelated to Aabar itself?" ... Pua alleged that Arul Kanda's refusal to provide a clear answer to the question only proved that Arul Kanda knew at all times of the entire scam and hid the information from the auditor-general and the PAC. He also 
said the question arises as to why Arul Kanda hid the information from Malaysians and failed to institute actions against the relevant parties in the "scam", including 1MDB officials, the fake Aabar BVI and its officers, since Arul's appointment was in January 2015, six months before Aabar BVI was liquidated.

Note also that the same news report had quoted verbatim several parts of Tony Pua's media statement including:

Indeed, no one is claiming that Arul Kanda signed the agreements and paid US\$3.51 billion to the fictitious Aabar BVI. But Arul Kanda was fully aware of the fake BVI, and hence had refused since the allegation arose last year to answer any questions on the status of Aabar BVI. ... How can Arul Kanda not know that the US\$1.367 billion of 'refundable security deposit', (the) US\$993 million of 'refundable options termination payment' and an additional US\$1.15 billion of 'top-up security deposit' have been paid to a company which [has] already ceased to exist! If he hid these crucial information, then he must be investigated for being an accessory to the entire scam.

It seems that the chickens have finally come home to roost! Not that it is all quite surprising. After all, it was in early March 2015 within just two months after Arul was brought into the 1MDB that a revealing piece appeared in the news portal The Malaysian Insider whose author (under the pseudonym name?) Sir Wenger J. Khairy who seemed to know much about the goings on in the corridors of power in Putrajaya the federal administrative center of Malaysia (see for example the latter half of the very piece!) had this to say ("1MDB: Abondon ship", 2015):

Over the weekend, the investigative portal, Sarawak Reports, released a deadly dossier of email conversations, internal documents, banking instructions and even Facebook updates behind 1MDB's fateful business venture with Petrosaudi. According to Sarawak Report, the deal was a sham and was used by Taek Jho Low to enrich himself to the tune of US\$700 million, courtesy of funds raised through a guarantee of taxations of the Malaysian people and revenue from her natural resources. This revelation effectively seals the current president's fate in 1 MDB. Arul Kanda has gone on record to say that he has no evidence of Jho Low's involvement in the management of the fund. Sarawak Report shows that either Arul was not being straightforward or he is clueless. Either way, the banking sector has lost faith with him. (Emphasis added.)

And pray tell the manner that the so called banking sector "has lost faith" in Arul? As the person Sir Wenger J. Khairy had next mentioned it:

A syndicate of banks responsible for arranging $1 \mathrm{MDB}^{\prime}$ 's bridge loan which was used to finance the acquisition of the power assets from Tanjong PLC refused to extend the loan. 1MDB's US dollar bonds are trading at substantial discounts to Malaysia's own bonds - even though it enjoys backing through letter of comfort that makes it effectively an obligation of Malaysia.

Before this effort to understand the former 1 MDB top gun is brought to a close, there are just a few things left which need to be stated out. Two of these came from Kee Thuan Chye and the third and last one from Tun Dr. Mahathir Mohamad. For the former, in the late April 2016 write up that was mentioned earlier, Kee Thuan Chye mentioned two quite damaging remarks against Arul (Chye, 2016). The first damaging account appeared as the first few lines in his write up:

Arul Kanda Kandasamy is not involved in any siphoning of funds from 1MDB to the wrong pockets. He was brought in to head the company long after the foul deeds had been done. He was brought in to rationalise the company and bring it back in the black. 'Rationalise' might even have been a nice 
word used for his job description - to mean cover up the dirt, if he found any. Well, from the Public Accounts Committee (PAC) report and some of the things he has said publicly, it appears that he did find dirt and he did cover it up. (Emphasis added.)

And the second and last damaging account which appeared not too long after that very quotation: "MP Tony Pua, a member of the PAC and 1MDB's closest observer, has called Arul a "liar". The fact that Arul has not defended his honour by, say, suing Pua, suggests that the accusation is true."

As for what originated from Tun Dr. Mahathir Mohamad, simply note what he posted in the first half of his blog posting in June 2015 - this was in response to Arul Kanda's explanation a few days earlier on how close to RM42 billion 1MDB funds had been spent on (Mahathir, 2015d):

1. I am intrigued by the ability of $1 M D B$ to invest 42 billion Ringgit in so many businesses. Really I should be fully satisfied with how 1 MDB expended the huge loan that it borrowed.

2. But unfortunately I am not. I am not, because the information came from the current CEO, Arul Kanda Kandasamy. And Arul has been caught lying quite a number of times.

3. Almost as soon as he took over management of $1 \mathrm{MDB}$ he announced that the money from Cayman's Island has been returned. He said clearly and openly that he saw the cash i.e. one billion dollars in cash. Then he said it was statements. What are the statements? Anyway in the end the bank said no cash and only documents were deposited in it and the documents carried false signatures.

4. He must have told the Prime Minister about this fantastic pile of dollar notes so the Prime Minister answered the question in Parliament that the cash is in the bank in Singapore. It cannot be brought back because Bank Negara asks too many questions. The Finance Minister must approve or disapprove all Bank Negara strictures or approvals.

5. Then the banks denied that the cash is in the bank. Embarrassing. The vision has disappeared. No. It is not cash. It is documents. No, it is units. What units? Dunno. Which bank? Not clear. The mystery deepens.

6. So when Arul announced the investments of 42 billion Ringgit, could it be something else that he saw which was not there. And do people use borrowed money to pay tax? What tax? No profit was declared but tax was paid. How much? Cost of managing 1MDB run into billions!

7. In any case, many names which are known to have received money from 1MDB are not mentioned. Lots of money went to Hong Kong companies with funny names.

8. Has nothing been paid to Petro Saudi, to Jho Low, to Brazen Sky and others. Jho Low denies but why has he not proven that he did not receive US 260 million (RM 988 million) from 1MDB to buy a bank.

9. Arul had lied before. It is not inconceivable that on the 42 billion Ringgit Arul may be lying again. Where a chunk of the 42 billion Ringgit went is still questionable. (Emphasis added.)

\subsection{Without the slightest of doubt it is fraud through and through!}

That 1MDB is not the case of corporate governance gone wrong, inappropriate business model and the like and instead $1 \mathrm{MDB}$ is a true blue case of fraud perpetrated by those in management position in collusion with others from outside the entity is pretty clear to some. And such realization took place quite early on - several years before the 1MDB's debilitating saga exploded in the Malaysian public and world arena in 2015. Hence, the following describes what emerged pre 2015 to be followed by the 
delineation of more revealing news reports in 2015 and 2016. Also, there is a bit delineation of what took place overseas. With all that pointed out, the section comes to an end with the listing down of the headings of online write ups detailing out management fraud in 1MDB which interested readers may want to locate for additional reading.

\subsubsection{Pre 2015}

Among those who understood 1MDB for what it really is quite early on is of course the parliamentarian Tony Pua. In a piece by Hazlan Zakaria published in the Malaysiakini in 2012 in regard to the parliamentary Public Accounts Committee's probe into allegations of questionable investment by 1MDB facing difficulty to obtain documents from the company (with mere one out of seven furnished!), in the second last line the following was mentioned (Hazlan, 2012): "Petaling Jaya Utara MP Tony Pua alleged that it is akin to a 'Ponzi Scheme', referring to a recent Wall Street scandal which saw millions lost in bogus investment schemes."

And pray tell as to which deals concerning the 1MDB that reflected such a scheme? Well, at the end of March in the following year 2013, P. Gunasegaram had made it all quite clear. He wrote early on (Gunasegaram, 2013):

DAP MP Tony Pua says 1Malaysia Development Bhd is a giant ponzi scheme whereas 1MDB describes itself as a strategic development company. ... Its accounts since setting up in late Februrary 2009 to the year ended Mar 31, 2011... indicates that the profits made to date are largely paper gains which have no impact on cash flow... If not for some paper transactions and revaluations, 1MDB would not have reported any profits, which no doubt led to Pua's assertion that it was a Ponzi scheme.

And the so called Ponzi Scheme has benefited some parties from overseas! Wrote Gunasegaram further: "As at Mar 2011, 1MDB had loans of RM6.69 billion. That means that over 85\% of the money that it had borrowed were simply on lent to PetroSaudi, not for the short term, but for long period of 11 years for RM4.14 billion and five years for RM1.57 billion. Of every ringgit that $1 M D B$ borrowed, 85 sen went to PetroSaudi!" (Emphasis added.) Related to this, Gunasegaram had mentioned:

Why is $1 M D B$ raising funds for PetroSaudi? And can we be sure that PetroSaudi will pay back the sums in bullets, one maturing in five years and one in 11 years? Recall that 1 MDB has no recourse to anything else but a guarantee from PetroSaudi for this. Everything so far has revolved around PetroSaudi. If PetroSaudi, for any reason cannot pay back the debts, $1 M D B$, is dead. It is simply inconceivable that a national strategic development fund can risk public money like this - and to the tune of nearly RM6 billion with interest yearly accumulating at the rate of nearly RM500 million a year.

And in the last section of the piece, he wrote revealingly:

For roughly the first two years of its operations, 1MDB has made profits only because of a gain on a transaction and a revaluation. Otherwise it would have been in the red. And it has had no achievements to speak off in this period. It has merely put funds it raised through a favourably priced RM5 billion bond issue and more into PetroSaudi. Why? Is PetroSaudi part of a scheme to suck money out of $1 M D B$ and leave it high and dry? ... To sum up, $1 M D B$ had nothing to show for its first three years of existence and earned the dishonour of simply funnelling more than four out of every five ringgit it borrowed to PetroSaudi. And by no stretch of even the most expansive imagination can one 
conclude that this is the work of a strategic development company that leads in market-driven initiatives to help transform Malaysia into a thriving economy. (Emphasis added.)

Perhaps 1 MDB is nothing but a Ponzi scheme should be quite clear to even the dumbest among us when Gunasegaram had laid bare the following devastating details:

One thing for certain, there is too little information on PetroSaudi and to put so much of our money with them is asking for trouble. 1MDB needs to do some explaining and so far it has not. Pua, who is a member of the Parliamentary Public Accounts Committee, said the committee questioned 1MDB officials about Petrosaudi but little was forthcoming. "We questioned them about Petrosaudi and asked for documents but all they gave us was press releases," he said in an interview.

But if all that has still failed to be crystal clear to some, Gunasegaram one year later in early March 2014 had written about a series of terrible moves by the 1MDB to that date (Gunasegaram, 2014):

... it has a strategic role in growing the economy via global partnerships and promoting foreign direct investment or FDI. It is supposed to catalyse new sources of growth. How much has it done in those terms? Nothing, yes nothing! First it borrows up to RM20 billion in loans and misprices them deliberately to lose RM4 billion to the favoured. ... What a great start for a strategic development fund! About the first investment it made was in a joint venture with PetroSaudi of about RM6 billion under rather dubious circumstances and transactions... Eventually, through a series of convoluted deals, it says it got over RM7 billion back but it is all stuck in Cayman Islands... It buys over RM10 billion worth of power assets, some of which are expiring soon, at substantially inflated prices. These include power assets of Tanjong, Jimah and Genting... Meantime it upped its loans by about RM10 billion to a total of some RM30 billion to fund the power purchases, its first solid - but overpriced business. (Emphasis added.)

And pray tell who had actually benefited from all that which the 1MDB had embarked upon? Well, as Gunasegaram had succinctly put it at the end of his piece: "1MDB is no strategic fund to help Malaysia it is a scheme to enrich some at our collective expense!!" It should also be worth noting that in the rest of Gunasegaram's write up there were additional details of devastations through the 1MDB by the few for the rest in Malaysia.

All in all, in all honesty, the 1MDB had brought nothing but misery for Malaysia, its people and their future. Also, from the very beginning of its existence it appeared that it was around merely to benefit a selected few who as the year 2015 arrived had however started to see that their "good fortune" had started to show signs of dwindling down.

\subsubsection{5}

All that concerning the 1 MDB which were in the news prior to 2015 appeared to be pale in comparison to those found in news reports that started to come out in early 2015. In particular there were more unsavory details revealed regarding the transactions between 1MDB and PetroSaudi mentioned earlier. For example, in early March the news portal The Malaysian Insider had the following introduction ("Najib cannot dissociate himself", 2015):

Prime Minister Datuk Seri Najib Razak cannot disassociate himself from 1Malaysia Development Berhad (1MDB) and its financial scandals, DAP MP Tony Pua said today. He said that if the documents and email communications between businessman Low Taek Jho or Jho Low and his cohorts, exposed 
INTERNATIONAL JOURNAL OF ACADEMIC RESEARCH IN BUSINESS AND SOCIAL SCIENCES

Vol. 9, No. 3, March, 2019, E-ISSN: 222 2-6990 @ 2019 HRMARS

by whistleblower site Sarawak Report, were genuine, Putrajaya must answer for the abuse of power in siphoning money from the wholly-owned Ministry of Finance subsidiary.

Also mentioned in the same news report was this:

The Petaling Jaya Utara MP was referring to Sarawak Report's claims that the US\$700 million (RM2.5 billion) loan 1 MDB repaid to PetroSaudi International (PetroSaudi) in 2009 had been channelled to a company allegedly controlled by Low. Citing documents and email correspondence, Sarawak Report said Low had orchestrated the entire joint venture between 1MDB and PetroSaudi in 2009.

A week later there appears to be more clarity as the following was reported in the same news portal (Anisah, 2015a):

Whistleblower site Sarawak Report's recent exposes on 1Malaysia Development Berhad (1MDB) have provided enough evidence for Malaysian businessman Low Taek Jho, or Jho Low and ex-1MDB CEO Datuk Shahrol Halmi to be charged under two laws, PKR said today. PKR secretary-general Rafizi Ramli said Prime Minister Datuk Seri Najib Razak was also liable, adding that he would be lodging a police against all three tomorrow at the Dang Wangi police station in the capital. Rafizi said the leaked PetroSaudi email correspondence was enough to charge Low and Shahrol with criminal breach of trust and violating the Anti-Money Laundering, Anti-Terrorism Financing and Proceeds of Unlawful Activities Act 2001.

And in the same news report the appalling details regarding 1MDB-PetroSaudi collaborations over a period of three years were revealed:

$1 M D B$ 's links to PetroSaudi were thrown in the spotlight after Sarawak Report claimed that Low had orchestrated the 2009 joint venture between the two companies to siphon off US\$700 million from $1 M D B$. Sarawak Report claimed that PetroSaudi agreed to act as a "front" for Low in future deals, and that the firm had no wealth or assets of its own. The joint venture fell through only six months later, but 1MDB continued to conduct deals with PetroSaudi, and lent it another US\$500 million in 2010, and another US\$300 million in May, 2011, for reasons it has never disclosed. (Emphasis added.) In the following month in April 2015, in the Free Malaysia Today, there were more shocking news. In the very first line (Fuentes, 2015): "Tony Pua has called on Prime Minister and Finance Minister Najib Abdul Razak to stop lying and covering up for 1Malaysia Development Berhad (1MDB)..." And there was also the following which had made clear the despicable acts that had occurred:

"Malaysians are being robbed blind via $1 \mathrm{MDB}$, and the Prime Minister can still tell us 'to give time to 1MDB to develop or liquefy assets'," said the Petaling Jaya Utara MP. "Billions of dollars have been misappropriated, bank statements falsified and the mastermind exposed." From the information which has been exposed, pointed out Pua who is also DAP National Publicity Secretary, it was blatantly obvious that Malaysians have been brazenly robbed by Jho Low, abetted by his accomplices and conspirators, via 1MDB. (Emphasis added.)

In much of the rest of the news report there were details provided regarding the supposed parking of the USD1.1 billion of proceeds from the disposal of 1MDB's investment in Cayman Islands in BSI Bank, Singapore with the then prime minister as mentioned by Tony Pua pretending all along as if there was nothing much for the nation to be concerned about. Also, it should be worth noting that in the last two 
lines of the news report there were upsetting revelations made in regard to what had really taken place behind the supposed 1MDB-PetroSaudi collaborations:

In a even bigger expose on Thursday, The Sarawak Report revealed documents showing how out of USD860 million (RM3.1 billion) which was siphoned from 1MDB to Good Star Limited via the PetroSaudi International joint venture, USD529 million (RM1.9 billion) was subsequently transferred to the Abu Dhabi Kuwait Malaysia Investment Corporation (ADKMIC) account with BSI Singapore between June 2011 and September 2013. The Singapore authorities have since reportedly confirmed that the beneficial owner of the ADKMIC account was Jho Low.

On the very same date that this very news report came out there was another news report from another news portal providing additional details regarding the ADKMIC ("Stop lying", 2015): "ADKMIC was the name of the company Low fronted in July 2008, which had previously engaged in the buy-up of a 53\% shareholding in the Utama Banking Group (UBG), a company controlled by Tun Abdul Taib Mahmud's family..."

Also, later in April 2015, in The Malaysian Insider, the following was mentioned at the beginning of the news report ("Najib's continued silence”, 2015): “Datuk Seri Najib Razak's continued silence on the recent exposés on 1Malaysia Development Berhad (1MDB) directly implicates him in the scandal, DAP MP Tony Pua said. He accused the prime minister of trying to stall for time to protect those named by whistleblower site Sarawak Report in its exposés, including businessman Low Taek Jho, who is better known as Jho Low." And not long later, the following was mentioned:

The Petaling Jaya Utara MP said Najib could immediately confirm or deny that funds from 1MDB had been transferred to Low's companies, as the finance minister would likely have access to the documents cited by Sarawak Report in its exposés. ... Pua said Najib's decision to remain quiet in the face of Sarawak Report's accusations left Malaysians with no choice but to believe the exposés.

And came right after was the following pointed remarks from Tony Pua:

As result, not only do Malaysians lose their trust in the prime minister, we lose our confidence with the Royal Malaysian Police because they have not acted with any degree of urgency to investigate by far the single largest financial robbery in the history of Malaysia. With Jho Low's fingerprints all over 1MDB, its RM42 billion of debt and missing billions of dollars, we would have expected Tan Sri Khalid Abu Bakar to have at the very least invited Jho Low for a conversation with the police, if not already issued a warrant of arrest."

In the rest of the news report, there were vivid details given on 1MDB and PetroSaudi business dealings which appeared not to have been well known earlier:

According to Sarawak Report, US\$1.19 billion of the US\$1.93 billion that 1MDB lent to PetroSaudi ultimately went to Good Star Limited, a company it claimed was controlled by Low. This included the US\$700 million Good Star allegedly siphoned from 1MDB's now-ended joint venture with PetroSaudi International, which was allegedly orchestrated by Low. Good Star had also received an additional US\$160 million from a Murabaha Loan agreement signed between PetroSaudi and 1MDB, which was also masterminded by Low, Sarawak Report said. Another US\$330 million loan 1MDB had issued to PetroSaudi International in 2011 was actually deposited into the account of Good Star, said Sarawak Report. It also said Good Star was found to have transferred over US\$500 million to one of Low's bank accounts at BSI Bank Limited in Singapore in 2011 and 2012. (Emphasis added.) 
Two days after all that was reported, in the same news portal the following was mentioned ("Freeze Jho Low's assets", 2015):

A DAP lawmaker wants the police to immediately freeze the assets of businessman Low Teck Jho as they may have been bought with funds siphoned from troubled Malaysian state investor 1Malaysia Development Berhad (1MDB). Petaling Jaya Utara MP Tony Pua said it was bewildering why the police have not taken any action against Low, also known as Jho Low, even after months of exposés on how the Penang-born businessman was tied to scandals in 1MDB.

Next, there was description as to what Low had committed:

Low has been a central figure that keeps popping up in some of 1MDB's most spurious deals such as the botched PetroSaudi International venture worth US\$1.83 billion (RM6.59 billion). In that deal, Pua claimed that Low pocketed US\$1.19 billion directly via the company Good Star Limited, while US\$260 million was used indirectly to acquire UBG Bhd in Malaysia.

And of course there was the quotation from Tony Pua that came right after the delineation of the alleged wrong which Low had committed: "The evidence trails have already been carefully laid out for the police and yet, after months since the exposés, no concrete steps have been taken to try to put these robbers behind bars. The police for example, haven't even questioned Jho Low."

And before the month of April for 2015 is left behind, there is perhaps the need to touch on what Tun Dr. Mahathir had mentioned regarding the matter of money disappeared or lost as far as the 1MDB is concerned. In his $100^{\text {th }}$ posting for his blog, he mentioned early on (Mahathir, 2015a):

3. Governments can lose money through bad investments. We would know where the money is lost. But when huge sums of money disappear, then those entrusted with its management must answer for the disappearance. Disappearance is different from just losing. Disappearance is about money lost which cannot be traced. This can be because of corruption or theft. (Emphasis added.)

In a posting marked by the use of direct (numbers) and indirect (words) signs of "corruption or theft" giving substance to that very last line of the paragraph three quoted above Tun has his posting ended with the following: "29. It is this disappearance of a huge amount of borrowed money by 1MDB and the inability to answer questions regarding what happened to the funds that disqualifies Najib from being Prime Minister of Malaysia."

Regarding the signs for corruption or theft in $1 \mathrm{MDB}$, it seems that there is the tendency for some parties to give priorities to the direct ones comprising of those with outright ringgit amounts or some other numbers. In the newspaper The Star for example, the following was reported (Gasper, 2015):

In another development, Dr Mahathir in his latest blog posting claimed that he could not account for assets backing some RM27bil of the RM42bil loans taken up by 1MDB. He said that of RM42bil, he could only account for about RM14.7bil in purchases that ranged from power plants to land for property development. Dr Mahathir said the "disappearance" of a huge amount of borrowed money and the inability to answer questions on it led him to pressuring Najib to resign. "These are all the purchases that are known. They all add up to RM14.7bil. So there is approximately RM27bil left. "Where is the rest of the money?" questioned Dr Mahathir. 
The same may perhaps be said for The Edge Financial Daily (Surendren, 2015) - but as opposed to the reporting by The Star did detail out on the various 1MDB purchases plus some other amounts or numbers that Tun had disclosed in his blog posting. But in the case of The Malaysian Insider it went for both direct and indirect ones ("Najib must step down", 2015). But even when that was the case The Malaysian Insider has failed to include in its reporting all of the indirect signs that point towards abnormal or unusual conducts. Hence, what are all the indirect signs of corruption and fraud as mentioned by Tun himself in his blog posting? To mention just a few:

- In Malaysia there is also off-budget-funds which may not be presented to Parliament but are still subject to scrutiny and approval of the Cabinet. Cabinet papers are secret of course. But in the case of $1 M D B$ the presentation to the Cabinet and approval by it seems to be unclear. There seems to be attempts to hide behind official secrecy. (Emphasis added.)

- What we do know is that $1 \mathrm{MDB}$ has as its advisor the Prime Minister and Minister of Finance. It is inexcusable that the management which is appointed by the PM would reject his advice. So like the British Advisor of old, the advice of the Advisor is a directive. Since then three CEOs of $1 M D B$ have resigned without explanation. Could it be because they could not accept the advice! (Emphasis added.)

- The Government invested one million Ringgit in the 1MDB. According to known records $1 \mathrm{MDB}$ then borrowed from various sources 42 billion Ringgit. A company with 1 million Ringgit capital with no assets cannot borrow 42,000 times its capital with no collaterals. That $1 M D B$ is able to do so is because of Government guarantees. In other words it is Government which is borrowing the money. If $1 \mathrm{MDB}$ loses money, the Government will bear the loss. Yet the operation of $1 M D B$ is not overseen by Government officers responsible for the management of Government funds. (Emphasis added.)

- Why has the $1 \mathrm{MDB}$ become controversial? What is wrong with $1 \mathrm{MDB}$ ? From the beginning it was wrong. It started off as an off-budget and it was not put before the Parliament. The money was borrowed. So it is not sovereign wealth but sovereign debt. The bond raised by Goldman Sachs costs more than is usual for Government borrowings. The interest rate at $5.9 \%$ was too high. Government loans usually attract about 3\% or below. (Emphasis added.)

- Purchase of Tanjong Energy (now known as Powertek Energy Sdn Bhd) from Ananda Krishnan for RM 8.5 billion. This is higher than market price. The licence was about to expire. Purchase of Genting Sanyen Power (now known as Kuala Langat Power Plant) for RM 2.3 billion. Again high above market price. The licence was about to expire.

- More than 1billion US Dollars were said to be paid to Petro Saudi without verification as to the value of this company or its assets. (Emphasis added.)

- In Malaysia the PM and DPM usually hold one extra portfolio. Usually the Ministry of Home Affairs and Ministry of Defence alternate between the two. Occasionally while waiting for suitable candidate, the Ministry of Finance is held by the PM. Dato Sri Najib however prefers to keep the Ministry of Finance under him all the time. He has appointed a second Minister of Finance. This is his prerogative of course, but he must ultimately be responsible for what happens to the country's finances. (Emphasis added.)

The indirect signs of corruption or fraud raised by Tun have among them those with no ringgit amounts or numbers disclosed - but these are just as important as the direct signs or those having a mixture of 
direct and indirect signs in them particularly when interested parties are looking around for the so called tell-tale signs for fraud perpetration or corrupt activities by suspected individuals or organizations. Why? Because the words describing these tell-tale signs may just very well be the kinds found in other cases similar to $1 \mathrm{MDB}$ even though the ringgit amounts of concern may not reach tens of billions or are yet to be detailed out.

Before the year 2015 is left behind there are additional two pieces of writing which need to be looked into to crystallize further what has been noted earlier on crime perpetrated in $1 \mathrm{MDB}$. One came out in early June in the form of a blog posting by none other than Tun Mahathir himself and the other was a news report that were concerned with a Barisan Nasional (BN) politician. From the former note the following which appeared as the first and eleventh paragraphs of his blog posting in early June on the so called restructuring efforts done by the federal government then on 1MDB (Mahathir, 2015c):

1. The 2nd Finance Minister has presented Cabinet with a restructuring plan for 1MDB which will solve all it's problems. I would like once again to repeat that repayment of the debt does not absolve the borrowers from responsibility for losing the money in the first place. The money is not lost through bad businesses but has simply disappeared. Somebody knows how the money disappeared and who has the money now. But that somebody is not telling.

11. The restructuring plan presented by the 2nd Minister of Finance cannot erase the problem of $1 M D B$, cannot erase the fact that money borrowed by 1MDB has disappeared, that the Government of Malaysia will lose billions of Ringgit. Part of the loan may be redeemed but a very substantial amount will remain. Certainly the restructuring will not result in the lost money being recovered.

As for the news report concerning a BN politician, it was at the end of May 2015, The Malaysian Insider had this reported ("Probe 1MDB directors", 2015):

Authorities must investigate whether 1Malaysia Development Bhd (IMDB) directors breached their fiduciary duties, Centre For A Better Tomorrow (Cenbet) co-president Gan Ping Sieu said today. The former deputy minister of Youth and Sports said there are doubts on whether 1MDB directors acted with the interest of taxpayers, who are shareholders of the debt-ridden strategic investment firm, when carrying out their duties. He said for the moment, 1MDB's explanation on criticism leveled against the company was not adequate.

\subsubsection{6}

Following all the breaking news on 1MDB in 2015, in the following year in April in the Malaysiakini and within days after the PAC report on 1MDB was tabled in Parliament, P. Gunasegaram wrote a piece listing down ten good reasons as to why the then prime minister should be held accountable for the miserable goings on in 1MDB (Gunasegaram, 2016). Without a doubt it is a brilliant write up that has numerous cut to the chase remarks.

One of these remarks is the piece's introduction: "Does the release of the Public Accounts Committee (PAC) report last week exonerate Prime Minister Najib Abdul Razak of all wrongdoing in relation to 1Malaysia Development Bhd as the usual suspects are claiming? Absolutely not, because Najib is ultimately culpable for everything that has gone wrong at 1MDB." Not long later the motive behind all the shameful acts which were associated with the 1MDB was mentioned as follows: 
Does that PAC report say that all monies are accounted for in 1MDB and there was no wrongdoing? Absolutely not, although some are trying to paint the picture that way. From all previous evidence, it is crystal clear that $1 M D B$ was not a mistake but a wilful, scheming, brazen, unprecedented and greedy pilferage of billions of ringgit of the nation's limited resources... (Emphasis added.)

Next, Gunasegaram in mere three sentences had captured what went absolutely wrong with the 1MDB when there was such menacing motive around:

Just to summarise, mispricing of loans alone at $1 M D B$ could have given others gains of as much as RM6 billion while a further RM4 billion involves strange collateral arrangements and exorbitant payments for options, clearly a means to siphon money out of $1 M D B$. Questionable asset selection accounted for some RM27 billion, while overpayment of advisers come up to some RM2 billion and a payment to a Jho Low-linked company came up to RM2.6 billion. That's almost RM42 billion lost and/or at risk. (Emphasis added.)

As for who should be held most responsible for the terrible goings on, there is no confusion as far as Gunasegaram was concerned. He wrote: "We give 10 reasons why Najib must be held accountable for $1 \mathrm{MDB}$ - he is more accountable than anyone else, including one former CEO who may become the fall guy for this entire sad, sorry episode." And just before he started the delineation of the very first reason, he had this mentioned: "Now back to those ridiculous, ludicrous and completely illogical attempts to absolve Najib of all blame for 1MDB. Here's 10 reasons why he is the person most responsible and should be held accountable." Also worth noting is what he wrote simply at the very end of the piece: "Yes, Najib is still very much accountable for $1 \mathrm{MDB}$. Nothing in the PAC report says otherwise. And nothing in the PAC report says that all the money at $1 \mathrm{MDB}$ is accounted for and that there were no questionable or corrupt practices at $1 \mathrm{MDB}$. Anyone who says otherwise is simply lying."

Now, among a total of ten reasons which Gunasegaram forwarded, there are several which point towards the willful conduct of fraud in $1 \mathrm{MDB}$. From the first half of the list there is the reason number three where he had among others written:

$1 \mathrm{MDB}$ is directly and wholly owned by the Finance Ministry through Minister of Finance Inc, its corporate arm. In fact, all shareholder resolutions under the law has to be signed by the finance minister who is the shareholder's representative. Further, according to Article 117 (c) of 1MDB's memorandum and articles of association, any financial commitment (including investment), restructuring or any other matter which is likely to affect the guarantee given by the Federal Government for the benefit of the company, the national interest, national security or any policy of the government, has to get written approval from the prime minister. Najib must have known about all of $1 M D B$ 's major dealings. (Emphasis added.)

If that is not clear enough of the presence of willful misconduct, note the following too for his reason number five:

Government-linked companies, or GLCs, have in the last few years undergone major transformation to strengthen their governance, ensure greater transparency, and set up detailed procurement practices, amongst others. While governance of GLCs, especially those under government investment company Khazanah Nasional Bhd, have improved tremendously over the years, it was rather a strange thing to set up a company which would run up RM50 billion in debt with none of the control procedures which are now standard practice in other GLCS. Why? (Emphasis added.) 
Failure to improve matters and worst the efforts to obstruct justice are two other reasons appearing in much of the rest of his excellent write up which strongly point towards a certain person's total culpability of the fraud taking place in $1 \mathrm{MDB}$. In regard to the former, Gunasegaram wrote: "Najib knew or ought to have known about the strange practices happening at 1MDB. ... Despite knowing about these activities, Najib did nothing to further investigate these activities, to stop them and bring the culprits to book." And crucially Gunasegaram had provided three instances of red flags where no investigation whatsoever came about afterwards:

In fact, former 1 MDB CEO Shahrol Azral Ibrahim Halmi had confirmed to the PAC that Najib approved the US\$1 billion initial investment in the highly dubious PetroSaudi venture, 1MDB's first major investment. Also, as shareholder representative, Najib would have had to sign termination letters for 1MDB's auditors after the auditors had raised important queries over the accounts of the so-called strategic development company. He would have known what were the issues the auditors raised when he decided to terminate their services. ... When 1MDB mispriced its first RM5 billion bond issue way back in 2009 and raised eyebrows and suspicions in the international financial markets, it would have been the time to act, bring the miscreants to book and put this sad excuse of a "strategic development company" back on the right path. But that did not happen, raising very serious questions as to Najib's role in the whole episode. (Emphasis added.)

And finally, when it concerns the then prime minister's efforts to obstruct justice, note the following which is Gunasegaram's reason number eight:

8. Najib quashed investigations into 1MDB. In fact, he quashed investigations into $1 M D B$ when the former attorney-general (AG) was removed under extremely strange conditions and a new one was appointed in his place. The new AG not only exonerated Najib of wrongdoing in the unprecedented RM2.6 billion (now RM4.2 billion) "donation", he dismantled a multi-agency investigative committee looking into $1 M D B$. Meantime, the auditor-general's report on $1 M D B$ which has been substantially leaked in the foreign media, continues to be a classified secret under the Official Secrets Act to prevent its dissemination within Malaysia. Why put the one serious investigation on $1 M D B$ under the infamous OSA if it is not to stop the spread of damaging information? (Emphasis added.)

Note that in just over a month plus following the publication of this crystal clear piece by Gunasegaram in the Malaysiakini, in theedgemarkets.com there was a news report on the failure of the 1MDB to provide certain bank statements to the Office of Auditor General for the investigation that the latter conducted on 1MDB (Fui, 2016b). In the news report, Tony Pua was quoted to have said:

This is clearly a cover up for 1MDB by the Minister of Finance himself. It is not only 1MDB, but the minister himself has answered that the documents could not be furnished to the Auditor General. ... If I want to get a copy of the bank statement of my bank accounts in the country or outside the country, I can get it in two weeks. Why $1 \mathrm{MDB}$ cannot get it in one year? Unless there is something that $1 \mathrm{MDB}$ did not wish to disclose to the Auditor General, or there is something it wishes to hide, because there is fraud in $1 \mathrm{MDB}$. There was fraud happening and monies went missing, that's why $1 M D B$ did not want to get the bank statements and furnish to the Auditor General. (Emphasis added.) All in all and needless to say, P. Gunasegaram in April 2016 and Tony Pua in the following month are for certain not the only ones who claimed that there was fraud perpetrated in 1MDB - following the release of the PAC report. The evidence of such may be found in numerous news reports. The following provides 
the headlines to a selection of them coming out in either theedgemarkets.com or Malaysiakini within a period of just a month between the first week of April and the first week of May 2016:

theedgemarkets.com

- Najib must be held accountable for $1 M D B$, says Tony Pua (April 7, 2016)

- PAC and AG's 1MDB finding 'confirms gross mismanagement' - Tony Pua (April 7, 2016)

- Ex-1MDB CEO Shahrol Halmi must be held accountable for 1MDB's financial weakness - PAC (April 7, 2016)

- $\quad$ PAC deputy chair urges MPs to take action against 1 MDB's management (April 7, 2016)

- 'Najib must be held accountable for $1 \mathrm{MDB}^{\prime}$ (April 8, 2016)

- He did no wrong? (April 11, 2016)

- DAP demands police to investigate and arrest all parties involved in 1MDB scam (April 12, 2016)

- Cover Story: He did no wrong? (April 28, 2016)

\section{Malaysiakini}

- Shahrol not only one to blame for 1 MDB failures, says NGO (Apr 10, 2016)

- Resign for 'stupid' signing of 1 MDB docs without reading, Dr M tells Najib (Apr 15, 2016)

- Kit Siang: Time for new PM to clean Augean Stables (Apr 19, 2016)

- 'Act against ex-1MDB directors for possible breach of duty' (May 6, 2016)

Finally, in July 2016, there was a bombshell of a news report which should frustrate attempts by anyone trying to convince others that the terrible goings on in 1MDB had nothing to do with fraud. And the news report revolved upon what took place in the United States. Indeed, that which took place in July 2016 in the United States provided the early signs that finally God's willing there is light at the end of the long, dark and greasy tunnel! In short, the truth and justice that many from within and outside Malaysia have been looking for shall finally be met in the foreseeable future - now that the United States federal government has come into the picture! This and more as far as 1MDB's overseas development are described next.

\subsubsection{Overseas development}

The revelation in a news report in May 2016 mentioned more than once above that the Auditor General had failed to be furnished with the 1MDB overseas' bank statements even after having waited for a year for the $1 M D B$ to do just that was quite big. But the news report in July 2016 concerning what took place in the United States the day before was much, much bigger. As mentioned in the news report (Amarthalingam, 2016): "Yesterday, U.S. Attorney-General Loretta Lynch said the U.S. Department of Justice had filed a complaint to seize assets worth more than US\$1 billion tied to money stolen from 1MDB, as part of US\$3.5 billion funds misappropriated by the institution." And pray tell the motives behind the US government's move? As stated in the news report: "Lynch said the U.S. authorities' action was part of an effort to combat global corruption and ensure the U.S. would not serve as a "safe haven to those who have illegally used public funds for private gain"." 
Devastatingly in that same news report, the following was also mentioned: "Azmin [the then menteri besar of Selangor] quoted Lynch as saying that the officials of the Finance Ministry-owned 1MDB treated the state investment fund like "a personal bank account" and "stole billions of dollars from the people of Malaysia"." Related to this, Azmin was quoted to say scathingly:

At last, after all these months of trying to whitewash the mother of all financial scandals in Malaysia, the truth concerning $1 \mathrm{MDB}$ has finally surfaced confirming beyond the shadow of a doubt, that there was indeed a conspiracy to defraud and launder billions of the taxpayers' money committed by those closely connected with those occupying the highest rungs of public office. ... As we have consistently maintained, Najib's decision last year to sack Deputy Prime Minister Tan Sri Muhyiddin Yassin, relieve the then Attorney-General Tan Sri Gani Patail of his duties and displace top MACC officers who were actively involved in the $1 \mathrm{MDB}$ investigation, strongly suggested a conspiracy to cover up the scandal. (Emphasis added.)

Just a month short for a full year in June the following year another interesting development had also taken place in the United States. As mentioned in a news report (Chiew, 2017):

More than US\$4.5 billion (S\$6.2 billion) in funds belonging to 1Malaysia Development Bhd (1MDB) has been allegedly siphoned off by high-level officials of $1 M D B$ and their associates, according to a 251-page asset seizure filing by the US Department of Justice (DoJ) on Thursday. In what was its third lawsuit against corruption linked to the Malaysian sovereign wealth fund, the US DoJ says it seeks to seize an additional US\$540 million worth of assets. Combined with the two civil forfeiture complaints filed earlier, this brings the total value of the assets the US DoJ is looking to seize to US\$1.7 billion. (Emphasis added.)

In that news report plus another one (Chan, 2017), there were the disclosures of numerous assets bought using the 1MDB stolen funds which could leave one dizzy by just reading through them all but which in all honesty could really be quite heart breaking considering how hard it has been for years and years now for millions of Malaysians to bring food to table when a few using their privileged positions could easily embezzle billions for the life of luxury and ease beyond anyone's wildest imagination! In the former, details of such life appear under the following headings (Chiew, 2017):

- Living a life of luxury on the high seas

- "Lights, camera, action!"

- Diamonds are a girl's best friend

- Art is where the heart is

- House of cards

- Share investments

Aside from the United States, Singapore is another country where the authorities are doing far more than investigations as far as the $1 \mathrm{MDB}$ is concerned. Check out the following which was reported in July 2017 in The Edge Financial Daily ("Jho Low denies", 2017):

Malaysian financier Low Taek Jho (Jho Low) has said attempts to link him to recent guilty pleas in the 1Malaysia Development Bhd (1MDB)-related probes are based on "unfounded assumptions", after Singapore prosecutors said he used money traceable to the Malaysian government strategic investment fund for his own benefit. Low is the central figure in investigations linked to 1MDB and received "huge" sums, the prosecutors said in court filings made public on Wednesday. ... Singapore's 
investigations into $1 M D B$-related activities have so far led to five convictions and with four people sentenced to jail. ... Singapore has imposed a total of S\$29.1 million (RM90.65 million) in fines on eight banks as part of its 1 MDB probes. Credit Suisse Group AG and United Overseas Bank Ltd were among the firms that paid penalties, while BSI and Falcon Private Bank Ltd were also ordered to shut their local operations. (Emphasis added.)

For more evidence of absorbing development overseas regarding 1MDB fraud, the following news reports covering period of two and half years from September 2015 to early March 2018 should be of interest:

- Hong Kong police launch probe into US\$250m linked to Najib (September 11, 2015)

- Najib to face US corruption inquiry, says New York Times (September 22, 2015)

- Doubts raised about Saudi 'donation' to Najib, reports WSJ (January 27, 2016)

- World media eyes on Malaysia after A-G decision on RM2.6 bil donation (January 27, 2016)

- Now, Hong Kong cops on $1 M D B$ case, says report (February 4, 2016)

- Salleh accuses WSJ of mounting anti-Malaysia agenda, running down Putrajaya (February 24, 2016)

- Special Report: Criminal charges in Singapore turn spotlight back on 1MDB's Cayman units (May 19, 2016)

- Six things you need to know about Malaysia's stunning 1MDB financial scandal AFP (June 27, 2016)

- 'Wolf of Wall Street' sued as US seeks 1MDB-tied assets (July 21, 2016)

- Is Najib's strategy to remain silent like a mouse, asks DAP's Pua (October 6, 2016)

- Falcon sanctioned for 1MDB breaches (October 11, 2016)

- Ex-BSI banker in 1MDB-linked trial worked for 'Jho Low' - witness (November 1, 2016)

- DAP's Pua demands Najib explain RM55b ECRL award to Chinese company (November 2, 2016)

- 'Ex-BSI banker Yeo pocketed US\$18m from 1MDB-linked dealings' (November 2)

- Najib's policy switch has bigger implications to Malaysia, says DAP's Pua (November 3, 2016)

- U.S. envoy chides Malaysia's Najib, says rhetoric sounded like Mahathir (November 4, 2016)

- Focus shifts to 1MDB bonds in ex-BSI banker Yeo's trial (November 4, 2016)

- Yeo Jiawei saw lifestyle 'upgrade' in 2014, and there are three other 'fake' Aabars (November 8 , 2016)

- Ex-BSI banker Yeo takes the stand on 8th day of trial, claims he was just taking instructions (November 11, 2016)

- Yeo Jiawei Trial in Singapore: Criminal trial of ex-BSI banker begins in Singapore (November 19, 2016)

- '1MDB set to repay IPIC with China's help' (December 8, 2016)

- Jho Low family dealt setback in move to claim assets in 1MDB probe (December 9, 2016)

- Jet, mansions figure in US\$232 mil foreign trust case to be heard in Auckland court (January 18, 2017)

- Jho Low denies wrongdoing claims linked to 1MDB (July 14, 2017)

- Singapore police are said to examine Goldman role in 1MDB deals (November 3, 2017) 
INTERNATIONAL JOURNAL OF ACADEMIC RESEARCH IN BUSINESS AND SOCIAL SCIENCES

Vol. 9, No. 3, March, 2019, E-ISSN: 222 2-6990 @ 2019 HRMARS

- DAP's Pua questions Putrajaya's silence over RM400m confiscated by Swiss authorities (March 1, 2018)

\subsubsection{The final word, is it?}

To help gaining a much better understanding on the allegation of management fraud in 1MDB, there are numerous sources available online for interested parties. In particular, from online news portals, some of the very best reporting dated from as early as early March 2015 to as recent as mid July 2017 include the following (where except for the first two that come from the Malaysiakini, the rest come from theedgemarkets.com):

- Najib's stepson the key for Low, says report (March 1, 2015)

- Anatomy of a money-spinner (December 14, 2015)

- How Jho Low used US\$260 million of 1MDB’s cash to buy UBG in 2010 (June 6, 2015)

- How Jho Low \& PetroSaudi schemed to steal money from the people of Malaysia via 1MDB (July 20, 2015)

- U.S. maps $1 M D B$ fraud trail from Kuala Lumpur to Hollywood (July 21, 2016)

- 1MDB: The inside story of the world's biggest financial scandal (July 29, 2016)

- Jho Low's schemes to scam 1mdb (August 11, 2016)

- Investigative Report on 1MDB: Jho Low pocketed RM516 million flipping 3 companies with help of 1 MDB cash (April 10, 2017)

- Investigative Report on 1MDB: Jho Low uses bearer share firms and those with sovereign names to mislead (April 10, 2017)

- WSJ: 1MDB, Jho Low under US\$2.2b deal probe by US Justice Department (June 13,2017$)$

- $\quad$ MDB Update: 'Looks like we may have hit a goldmin(e),' Jho Low wrote to family (June 29, 2017)

- How Jho Low provided conflicting agreements to Coutts, Deutsche Bank to siphon 1MDB money to Good Star (July 13, 2017)

- How Jho Low lied to banks to siphon 1MDB money into Good Star (July 14, 2017)

- How Jho Low \& PetroSaudi schemed to steal money from the people of Malaysia via 1MDB (July 20, 2015)

Just to give some evidence of such good reporting that can be found from the list above, note the following appearing in late July 2016 in the British newspaper The Guardian (and which comes as the bullet point number six from the top) (Ramesh, 2016):

According to lawsuits filed last week by the United States Department of Justice (DoJ), at least US\$3.5bn has been stolen from 1MDB. The purpose of the fund, which was set up by Malaysia's prime minister, Najib Razak, in 2009, was to promote economic development in a country where the median income stands at approximately $£ 300$ per month. Instead, the DoJ alleged that stolen money from $1 M D B$ found its way to numerous associates of Prime Minister Najib, who subsequently went on a lavish spending spree across the world. It also accused Najib of receiving US\$681m of cash from 1MDB - a claim he denied. (Emphasis added.)

Next, the writing specified the fraud over time in the following manner: 
The US justice department breaks the alleged theft down into three distinct phases: the first US\$1bn defrauded under the "pretence of investing in a joint venture between 1MDB and PetroSaudi"; another US\$1.4bn, raised by Goldman Sachs in a bond issue, misappropriated and fraudulently diverted to a Swiss offshore company; and US\$1.3bn, also from money Goldman Sachs raised on the market, which was diverted to a Singapore account.

It also quoted remarks coming from the US attorney general Loretta Lynch: "A number of corrupt 1MDB officials treated this public trust as a personal bank account. The co-conspirators laundered their stolen funds through a complex web of opaque transactions and fraudulent shell companies, with bank accounts in countries around the world, including Switzerland, Singapore and the United States." And the various manners that the stolen funds had been spent on and which were detailed out in the US Justice Department's complaint were also mentioned in the striking written piece early on as follows:

Money from $1 \mathrm{MDB}$, the US also claimed, helped to purchase luxury apartments in Manhattan, mansions in Los Angeles, paintings by Monet, a corporate jet, and even financed a major Hollywood movie. ... Najib... is not mentioned by name in the US lawsuits, which refer to him as "Malaysian Official 1". But the man at the centre of the intricate swindle depicted in the US lawsuits is an adviser to Najib: Jho Low, a Harrow-educated 29-year-old friend of the prime minister's stepson. ... In 2011, Low took a $20 \%$ stake in EMI, the world's largest music-publishing company, for US\$106m - in the same year, he bought a US\$30m penthouse for his father at the Time Warner Center in Manhattan, overlooking Central Park.

And the capturing of such free spending was concluded with the following remark:

All this and more is laid out in the US filing, which details claims of an amazing heist, carried out by conspirators who rinsed billions from the people of Malaysia through offshore accounts and shell companies in tax havens such as the Seychelles and British Virgin Islands. The scale of the enterprise echoes Balzac's maxim that behind every great fortune lies a great crime. (Emphasis added.)

Finally, it should be worth mentioning the quotation appearing in the last part of the brilliant piece coming from a top gun in the US's Federal Bureau of Investigation: "When the US Department of Justice laid out the case against 1MDB last week, it pulled no punches. "The Malaysian people were defrauded on an enormous scale," said Andrew McCabe, the FBI's deputy director." (Emphasis added.)

\subsection{PAC Report's Cautionary Note}

PAC tabled a 106-page parliamentary report on 1MDB in the Dewan Rakyat on 7 April 2016. It is a report with serious deficiencies in contents. And as perhaps to be expected too there were question marks in the fact finding process taking place over a period of almost a year leading to the issuance of the report. Both the report's contents and the fact finding process are discussed next. Note however that not everything is raised - only those which would be sufficient to show that the PAC report has to be taken with a handful of salts!

\subsubsection{Questionable contents?}

When the PAC report was tabled in Parliament on 7 April 2016, Tony Pua in theedgemarkets.com on the very same day was quoted to say (Ahmad Naqib, 2016d):

The tabling of the PAC report today, with the accompanying transcripts of all its proceedings since May 19, 2015, in Parliament has now fully vindicated us. The findings of the AG, summarised in the 
INTERNATIONAL JOURNAL OF ACADEMIC RESEARCH IN BUSINESS AND SOCIAL SCIENCES

Vol. 9, No. 3, March, 2019, E-ISSN: 222 2-6990 @ 2019 HRMARS

106-page PAC report, and the relatively brief conclusion by the PAC confirm gross mismanagement and wanton neglect of all principles of good governance and accountability.

And pray tell who was said to be the guilty ones? Well, in a press statement dated 7 April 2016 which was published the very next day at theedgemarkets.com, the then prime minister of Malaysia had said among others ("Statement by prime minister", 2016):

Having reviewed it, I note that the PAC's report shows that RM42 billion is not missing from 1MDB, as had been alleged by Tun Mahathir. However, the report has identified weaknesses in 1MDB's capital structure and management. ... Equally, it is now clear that Tun Mahathir's allegations against $1 M D B$ have been false. He was motivated by personal interest, not the national interest, and a desire to unseat the government.

Also, on April 7, 2016 the then Public Accounts Committee (PAC) deputy chairman Dr. Tan Seng Giaw was quoted to say in regard to the possible wrong doing by the then prime minister who chaired 1MDB's advisory board (Ahmad Naqib, 2016e):

Through our investigations, it was found he was not directly involved. His name only showed up due to his position in the advisory board. Besides that, the focus was mostly on the management. Executive officers would run the business and the people who monitor these things are the board of directors. Let's look at the people who are directly involved and figure out what actually went wrong.

With all this in the background, it was not surprising at all to find a few days later the following remark mentioned by the then Malaysia's ambassador to Indonesia Datuk Seri Zahrain Mohamed Hashim ("Media urged to access info", 2016): "The investigation conducted by PAC found weaknesses in 1MDB's management and also confirmed that there was no evidence to implicate Prime Minister Najib Abdul Razak in 1MDB's quandary." And it was not surprising also to get to read the following appearing at the end of the very same news report:

Zahrain said the issues surrounding $1 \mathrm{MDB}$ were actually about corporate governance but were subjected to investigations worldwide, after being turned into a political issue aimed at damaging the image of the prime minister. He held that allegations hurled at the prime minister with regard to 1MDB were hearsay, and that no party had been able to produce any evidence to prove otherwise, to this day.

Really? Hence, what is the following mentioned in The Edge Financial Daily on the very day that the PAC report was tabled in the Parliament (Ahmad Naqib, 2016c)?

Public Accounts Committee (PAC) member Tony Pua said Prime Minister Datuk Seri Najib Razak should be held accountable for the mishaps at 1Malaysia Development Bhd (1MDB), considering his position as the chairman of the advisory board. Pua said Najib was aware of the ongoings of the state investment company, as the premier had signed off the documents.

And regarding that second and final line of the quote, Tony Pua was of course referring to Clause 117 of $1 M D B$ 's memorandum and articles of association (M\&A) (which is given some elaboration at the end of the section below) which states that Najib's written approval is required to pass any deals, including decisions on investments and restructuring, as well as the appointment of company directors and senior management members. Related to this, Tony Pua was quoted to say in the very same news report: "The 
prime minister knew the deals, because he signed them off. One of the reasons Clause 117 was included is that its the key link to implicating the prime minister."

And yet if truth be told just about one news report after another following the release of the PAC report had made it quite clear that somebody else was responsible for all of the horrendous goings on in the $1 \mathrm{MDB}$ ! For example, on the very same day that the PAC report was laid out in the Parliament, a news report in the Malaysiakini had this mentioned ("Ex-1MDB CEO stresses", 2016): "The PAC, in its 1MDB Governance Management Control Report released in the Dewan Rakyat today, asked the authorities to investigate Shahrol Azral and other relevant officers. The PAC said Shahrol Azral must take responsibility for the government-owned strategic investment company's weaknesses and shortcomings." Also, in another news report in theedgemarkets.com on the very same date, it was mentioned (Ahmad Naqib, 2016d):

In a statement today, Pua, who is also Petaling Jaya Utara MP, said the Auditor-General's (AG) findings in the PAC report on $1 \mathrm{MDB}$ had vindicated $1 \mathrm{MDB}$ 's critics. ... Pua said the PAC report had requested Shahrol and related parties to be investigated following the announcement of the AG and PAC's findings. As such, he said the police must immediately investigate Shahrol and his associates as there was enough evidence to indict 1 MDB's top management and board of directors.

And related to this, Tony Pua was quoted to say:

The Inspector-General of Police must take immediate action to investigate [the former 1MDB chief executive officer] Datuk Shahrol and his associates. I will go further to call not only for Datuk Shahrol Halmi be sacked with immediate effect, but the entire board of directors who have failed to protect the interest of the Government and the tax-payers to be removed as well. There are many other shocking misdeeds and transgressions which have been disclosed in the PAC report, which won't be listed here in my statement. However, what is clear is that there is more than sufficient damning evidence to indict not only the entire top management but also the entire board of directors.

But really it was a news report in The Edge Malaysia Weekly a few days later that appeared to mince no words (Murugiah, 2016): "PAC, in its 106-page report tabled in Parliament last week, put the blame for all the troubles at 1 MDB squarely on his shoulders." Next, it had the PAC report quoted: "PAC is of the opinion that former chief executive of 1 MDB Datuk Shahrol Azral Ibrahim Halmi must take responsibility for the weaknesses. As such, we request enforcement agencies to investigate (Shahrol) and others in management."

And guess what was Shahrol's reaction now that he was specifically named as the person to be investigated by the authorities? In the Malaysiakini on the very day that the PAC Report was laid out in the Parliament, the following was mentioned as Shahrol's "full statement" ("Ex-1MDB CEO stresses", 2016):

Over the course of this investigation, I appeared before the honourable members of the PAC on multiple occasions. I gave them a full and honest account of my time as CEO of $1 M D B$. As explained to the PAC, I wish to emphasise again that there was no wrongdoing or illegal activity at the company under my watch. I will continue to extend my full cooperation, confident in the knowledge that I have done no wrong and have nothing to hide".

Whether or not he has done no wrong is to this very day a mystery since after the general election in May 2018 where now Umno-BN is replaced by the Pakatan Harapan as the political party in control of the federal government Shahrol Azral Ibrahim Halmi has been left virtually untouched - just like what 
happened when Umno-BN was still in power following the release of the PAC report! Perhaps there is no surprise for such since the widespread view among many is that he was just following instructions and not quite the protagonist that the PAC appeared to have made him to be in its report?

Note the following mentioned in a new report filed by Malaysiakini within days after the PAC report was tabled in the Parliament ("Shahrol not only one to blame", 2016): "Human rights group Proham today said that allegations of criminal breach of trust surrounding state-owned fund 1MDB is not the sole responsibility of its former chief executive officer." Related to this the Proham chairperson Kuthubul Zaman Bukhari and secretary-general Denison Jayasooria were quoted to say: "We express deep concern over the failure of the board of directors, the advisory council and the Finance Ministry to institute adequate checks and balances. We are not in agreement that the criminal breach of trust lies solely on the CEO of $1 M D B . . . "$

Also quite interestingly the same news report had mentioned the following: "... Proham said adequate constitutional safeguards are necessary to prevent any further abuse by the executive. It urges institutional reforms to be implemented to ensure all responsible for "neglect of their public duty" can be prosecuted." In this regard, Proham was quoted to say:

There is a need for further public discussion on whether government should be involved in business and financial investments as well as what effective monitoring mechanisms are necessary to prevent abuse of power. Furthermore there is also a need for a public discussion on whether the same person should hold the office of the prime minister and office of the finance minister. (Emphasis added.) Aside from Proham, it should also be worth noting the damaging remarks coming from Tun Dr. Mahathir Mohamad. In the Malaysiakini, within a week after the PAC report was tabled in the Parliament, Tun during a public forum on the PAC report was reported to have made the following claim (Alyaa, 2016a): "... the PAC report appears to have been "whitewashed" to free Najib from all allegations." Tun was also quoted to say next the following: "And to make it easier for us to believe that the report has nothing to do with Najib, it named Shahrol as a scapegoat." (Emphasis added.) That all this was really the case was substantiated by what appeared in the rest of the same news report.

Specifically, as if the efforts to exonerate the then prime minister had no limit and that it could go beyond logic, on the basis of the findings of the PAC report which clearly showed that under Clause 117 in 1 MDB's memorandum and articles of association (M\&A) Najib had to authorize all the major decisions made by the state-owned fund, his lawyer had put forward the negating argument "... that Najib's signature on $1 \mathrm{MDB}$ documents was merely to meet corporate governance requirements" and that "...the signing of the documents does not necessarily mean that the prime minister has knowledge of or makes the decisions on 1MDB matters." And Tun's scathing reaction to these remarks which was mentioned verbatim in the news report:

How do we authorise a document? By signing it. When we put our signature on a document, we authorise it. But Najib's lawyer said that it (signing a document) does not mean authorising it. Najib just signed; he does not know anything. He did not even read it. How can someone like this be the prime minister? I am asking Najib, based on his stupidity to sign documents without reading, that it is best for him to resign now.

With the PAC report rigorously trying to transfer blame to other parties and by doing so exonerate the then prime minister cum finance minister cum the head of the 1MDB advisory board (where he in actual 
fact playing the role of a key decision maker!) for all that were ugly and unbearable which took place in the company for years and years, perhaps it could be expected that other shameless acts concerning the very same report had also taken place bringing the overall picture that the PAC report is not of much value to those looking for truth and justice as far as the $1 \mathrm{MDB}^{\prime}$ s sick and debilitating saga is concerned! And these blatant acts are delineated next.

\subsubsection{Fact finding process went wrong?}

It may be safe to say that the process that the PAC undertook to finally get to issue its 1MDB report was disturbing to say the least. But if one is in the mood to take things lightly since the whole saga concerning the $1 M D B$ is truly quite depressing needing some laughter now and then perhaps comical is really the word to describe the PAC fact finding process. The three cases covered next (out of what appeared to be more than a handful around) are to provide the evidence of such leading to the picture that with these around there is a big question mark on the quality of the PAC fact finding process and in turn on the credibility of the PAC report issued.

Bank statements, where are you? Just a day after the PAC was tabled in the Parliament in April 2016, theedgmarkets.com had disclosed the following (Lakshana, 2016a):

1Malaysia Development Bhd's (1MDB) refusal to hand over its foreign bank account statements and that of its foreign subsidiaries to the Auditor-General (AG) and the Public Accounts Committee (PAC) has raised suspicions that the "billions of dollars" which a Wall Street Journal (WSJ) report said had gone missing from $1 \mathrm{MDB}$ are indeed missing, DAP national publicity secretary Tony Pua said today. The Public Accounts Committee (PAC) report on 1MDB was tabled in Parliament yesterday, revealing that the AG was unable to verify actual transactions between the state investment company and Good Star Ltd of US\$700 million and US\$330 million, as well as a sum of US\$3.51 billion paid to British Virgin Islands incorporated Aabar Investment PJS Ltd. Pua, who is also member of parliament for Petaling Jaya Utara, said although the PAC report on $1 \mathrm{MDB}$ never specifically stated that billions were missing officially, the matter remains that billions were unaccounted for and cannot be verified, as confirmed by the AG. ... He also noted that as a result of 1MDB's refusal to cooperate, the AG was also unable to ascertain the purported existence and value of a so-called US\$940 million worth of "units" parked at the Swiss Bank branch of BSI Bank in Singapore. (Emphasis added.)

In the following month of May Tony Pua was reported to have said that since May 2015 the Auditor General had requested the statements of bank accounts of $1 M D B$ and subsidiaries outside the country to no avail (Fui, 2016b). This was alluded to under the heading "2016" above. Specifically, in the news report, the following was mentioned:

The DAP's Tony Pua has accused Prime Minister Datuk Seri Najib Razak of covering up for 1Malaysia Development Bhd (1MDB) for not being able to furnish statements of bank accounts of 1MDB and subsidiaries outside the country, despite the Auditor General having requested the documents since May 2015. Najib, however said all documents in the hand of state fund 1Malaysia Development Bhd $(1 \mathrm{MDB})$ or being requested, have been sent to the National Audit Department.

And yet it was nearly one and a half years earlier in early December 2015 believe it or not following remarks by Tun Mahathir in his blog post demanding documentary proof from 1MDB for several items 
appearing in its financial statements and over money deposited by supposedly donors overseas into the personal bank accounts of the then prime minister originating (Mahathir, 2015b) that the 1MDB had mentioned in a press statement that it had already provided various investigating entities including the National Audit Department and PAC with the documented evidence ("Dr. Mahathir's claims", 2015):

$1 \mathrm{MDB}$ is and continues to be the most investigated company in the history of Malaysia. We have cooperated fully with the lawful authorities, which include MACC, PDRM (police), BNM (Bank Negara), the National Audit Department and PAC. Documentary proof and evidence has been submitted to these lawful authorities. Each of these lawful authorities has independently conducted investigations and publicly issued statements relating to 1MDB. (Emphasis added.)

As if the lie concocted is not bad enough, note also that in the same press statement the 1MDB had lambasted Tun Mahathir saying:

If Tun Mahathir is interested in the truth, he would allow these agencies to complete their investigations and await their findings. However, rather than doing this, Tun Mahathir continues to freely make unproven allegations without any investigation, without any reference to facts, and without any regard to the rule of law and due process. Through his statements, Tun Mahathir clearly shows his contempt and disdain of the various agencies that are investigating 1MDB.

Next, the 1MDB went for the kill:

This is despite detailed and factual clarifications being issued by $1 \mathrm{MDB}$, and that Dr Mahathir has repeatedly been proven wrong in his claim that 'RM42 billion hilang' (RM42 billion missing) from 1MDB. After 22 years in power, in his mind, only Dr Mahathir can be right. This is despite him being proven wrong on 'RM42 billion hilang' allegation and meekly confessing to not having evidence, when asked whether he would lodge a police report against 1MDB.

Missing attendees and other issues with the PAC hearings! Really? Regarding the missing attendees for the PAC hearings, note the following mentioned in late May 2015 in a news report in The Malaysian Insider ("Did Najib okay", 2015):

DAP today questioned the absence of 1Malaysia Development Berhad's (1MDB) top bosses and asked if the prime minister allowed them to skip the bipartisan committee hearing in Parliament. Gelang Patah MP Lim Kit Siang said this was one of the chief questions that the Malaysian public has been asking since it was made known that both $1 M D B$ group executive director and president Arul Kanda Kandasamy and board member Datuk Shahrol Halmi would not be attending the Public Accounts Committee hearing today. This comes after PAC chairman Datuk Nur Jazlan Mohamed said both had requested to postpone their attendance at the committee's hearing today. ... Lim also asked why PAC was not informed about Shahrol and Arul Kanda's "important overseas appointments" when notice of the hearing was handed to them two weeks ago. (Emphasis added.)

The very next day in another news report in The Malaysian Insider, more was revealed (Anisah, 2015b): The Public Accounts Committee (PAC) today dismissed 1MDB's top executive's excuse for failing to attend its proceedings, and said no more second chances would be given to them once they are summoned again. Datuk Nur Jazlan Mohd said 1MDB president and group executive Arul Kanda Kandasamy and former chief executive officer (CEO) Datuk Shahrol Halmi would be summoned after PAC called up auditing firms Deloitte and KPMG. ... Nur Jazlan said PAC had sent a letter to MOF 
INTERNATIONAL JOURNAL OF ACADEMIC RESEARCH IN BUSINESS AND SOCIAL SCIENCES

Vol. 9, No. 3, March, 2019, E-ISSN: 222 2-6990 @ 2019 HRMARS

officials on May 6, requesting Arul and Shahrol to appear before the committee on May 26. But yesterday, Arul said that 1 MDB only received the letter from MOF on May 21, and had responded that same day. (Emphasis added.)

And in still another news report in The Malaysian Insider in late May 2015 the Centre for a Better Tomorrow (Cenbet) co-president Gan Ping Sieu who was also a former deputy minister of youth and sports had mentioned that the finance ministry had a duty to ensure the directors it nominated into 1MDB attended the PAC hearings ("Probe 1MDB directors", 2015). He was also quoted to say: "The PAC should be accorded respect and importance. This includes not asking for postponements of hearings. Directors who fail to do so ought to be relieved of their duties immediately." And right after this quotation it is notable that the news report had this mentioned:

1MDB president and group executive director Arul Kanda Kandasamy and former CEO Datuk Shahrol Halmi failed to testify at the PAC hearing scheduled yesterday. The duo had put in an abrupt request for a 30-day extension before testifying to the PAC, citing important overseas appointments. The request was made four days before the hearing despite receiving two-weeks' notice from the PAC. That there were other problems related to the PAC hearings could be detected later with a news report that came out in early November 2015 where the following was mentioned ("Najib must appear", 2015):

The Gelang Patah MP [Lim Kit Siang] also accused the new Public Accounts Committee (PAC) chairman Datuk Hasan Arifin of having no sense of urgency or priority to complete investigations into 1MDB. He questioned why the PAC was only summoning 1 MDB president Arul Kanda Kandasamy on December 1, even though the latter appeared to be "ever ready to be available for an instant debate with Tony Pua". Lim also accused Hasan of being "soft" on businessman Low Taek Jho, after the latter said the PAC cannot summon the businessman due to legal issues.

And note also the quotation coming from Lim Kit Siang: "I call on Hasan to speed up the dates of hearing for Arul and the past 1MDB CEOs and operatives, as well as to summon Jho Low, so that the PAC can table a report on its $1 \mathrm{MDB}$ investigations in time for the PAC report to be debated by Parliament before it adjourns on December 3." As for the matter of having Low Taek Jho (and also his partner the then prime minister cum finance minister cum the head of the board of adviser of 1MDB) to face up to the PAC, this would not have been an issue at all in a "normal" country! After all, they were known quite early on world wide to have played the crucial role in all that happened or failed to happen as far as the 1MDB was concerned. And yet...!

In another case study, this matter of failing to call up certain personalities to the PAC hearings may get to be elaborated. For now the extent of the tragicomedy of the PAC's failure to call up the two to come to its hearings may be seen in the headings of a sample of news reports next (where all come from theedgemarkets.com except for the first where it comes from The Malaysian Insider):

- PAC to quiz those linked to 1MDB (May 4, 2015)

- PAC says there is no need at the moment to call up Najib and Jho Low for 1MDB probe (May 19, 2015)

- Khairy wants PAC to probe Jho Low over $1 M D B$, says report (May 20, 2015)

- 'No need to call Najib and Jho Low for now' (May 20, 2015)

- PAC chief unsure if Jho Low can be summoned as 'not directly' involved in 1MDB (November 5, 2015) 
Believe it or not, there was in fact sentence deletion! OMG, OMG! But perhaps the subject matter of certain bank statements which fail to be submitted and missing attendees in the PAC hearings are not as horrifying as the next terrible act: the deletion of one single but quite significant sentence from the PAC report! The sentence is concerned with Bank Negara's information that Good Star, in which US\$1.03 billion from 1MDB's joint venture with PetroSaudi International was diverted to, was owned by an individual (Jho Taek Low) and not linked to the PetroSaudi group as claimed by those associated with the 1MDB. Of interest are two news report: one in the Malaysiakini almost two weeks after the PAC report was tabled in Parliament (Zikir, 2016) and the other in The Edge Financial Daily two days after the news report from the Malaysiakini had come out (Hun, 2016b).

Note the following reported in the news report by Malaysiakini (Zikir, 2016):

Opposition members of the Public Accounts Committee have accused their committee chairperson Hasan Arifin of editing the PAC report on 1MDB without the committee's approval. Petaling Jaya Utara MP Tony Pua claimed today Hasan had cut out a sentence in the report on the Jho Low-linked firm Good Star Ltd. Pua said the removed sentence reads: "Bank Negara Malaysia had been informed voluntarily by the authorities of that country that Good Star Limited is a company owned by an individual that has no links to PetroSaudi Group." This sentence, he said, had been approved by all PAC members in their working draft but it did not appear in the final published report. (Emphasis added.)

And in case if all that has failed to make it crystal clear as what exactly was the shameful going on, note the following mentioned in the news report by The Edge Financial Daily (Hun, 2016b):

On Monday, Pua and other opposition members in the committee accused Hasan of removing a key sentence from the PAC Report after the report had been approved by the committee. "This sentence states that Bank Negara Malaysia has been informed by the relevant overseas authorities on a voluntary basis that the ultimate beneficiary of Good Star Ltd is an individual unrelated to the PetroSaudi group," said Pua. He said 1MDB had made payments of US\$700 million and US\$330 million to Good Star in 2009 and 2011 respectively even though the funds were meant for its investments in PetroSaudi. (Emphasis added.)

And pray tell, what did the PAC report disclose instead? As mentioned in the news report by the Malaysiakini, the PAC report had disclosed that the former 1MDB chief executive officer Shahrol Azral Halmi had submitted documents to the PAC showing Good Star was a PetroSaudi subsidiary (Zikri, 2016). But do note on the following mentioned in the other news report in The Edge Financial Daily (Hun, 2016b):

Pua said the deleted portion was crucial to the entire investigation of $1 M D B$ because the company and its executives had testified to the PAC that Good Star is a subsidiary of PetroSaudi, but were "unable to provide any concrete evidence, such as a company search or certificate of incorporation from the relevant authorities, despite repeated requests to back up their claims to both the auditorgeneral and the PAC". (Emphasis added.)

And related to this Tony Pua was quoted to say: "All 1MDB could provide was a letter dated 2015 from PetroSaudi to 1MDB making a claim that Good Star Ltd was part of the PetroSaudi group. This letter would certainly hold no water in any court of law and the PAC would make itself a laughing stock of the world if we were to accept the letter at face value." 
Also note that in the Malaysiakini news report, it was mentioned that Tony Pua had read out a statement made by all the opposition PAC members that deleting the sentence was an offence (Zikri, 2016). In regard to this, he was quoted to say: "Cutting out a sentence approved by the PAC is clearly in breach of the Standing Orders and arouses suspicion towards the PAC chief's intention to close the case." Hence, they demanded Hasan to rectify this error immediately by tabling a correction in Parliament. In addition, they demanded Hasan to release two Hansards of PAC hearings which had failed to be made public. One was concerned the PAC's session with the auditor-general and the other involved PAC meetings on the preparation of the report on $1 \mathrm{MDB}$.

Cringe worthy or not, the PAC chairperson Hasan Ariffin in his reaction to all this had claimed that the sentence deletion in no way affected the final report by the PAC on 1MDB ("Editing of sentences", 2016). He was also quoted to say: "Entering a statement which is unclear or being investigated is something prejudicial and all PAC members should convince the authorities to conduct further investigations before making a statement." As perhaps to be expected such statement would hardly satisfy anyone.

Hence, in theedgemarkets.com on the very next day, Tony Pua was reported to have claimed "in a statement" the following (Hun, 2016a): that "... the PAC did not empower Hasan to delete the portion of the report" and that "... PAC members had at the committee's final meeting approved the report's final draft, which included the information on Bank Negara's findings." Also note that in the news report in The Edge Financial Daily mentioned earlier Tony Pua was said to have raised the question as to whether the PAC chairman was "... questioning and challenging the authority and investigative findings of Bank Negara." And, related to this, Tony Pua was quoted to say (Hun, 2016b): "If he is questioning the findings of Bank Negara, then why did he persistently, as recorded in the Hansard on at least five occasions, refuse our request to call Bank Negara to testify to the PAC?"

A week later in late May 2016 following the revelations made by The Wall Street Journal on the contents of a Bank Negara Malaysia letter stating that the owner of Good Star Ltd was none other than Low Taek Jho, in the theedgemarkets.com the following was mentioned (Lakshana, 2016d):

Public Accounts Committee (PAC) member Tony Pua has called for the resignation of PAC chairman Datuk Hasan Arifin for allegedly lying to the parliamentary panel. ... Pua said Hasan should resign for allegedly lying to the committee, suppressing evidence, covering up wrong-doings and obstructing investigations into 1Malaysia Development Bhd (1MDB). (Emphasis added.)

And next Tony Pua was quoted to say scathingly: "It cannot be clearer that Datuk Hasan Arifin has been nominated by Datuk Seri Najib Razak and Barisan Nasional to hamper and cover up the investigations into 1MDB. The PAC chairman has denigrated his parliamentary position to become a tool to help the crooks who stole billions of dollars of Malaysian tax-payers' money." (Emphasis added.) Also, the same news report had subsequently disclosed: "Pua said the Bank Negara letter, if taken into consideration by the auditor-general and the PAC, would have made the PAC report even more devastating as fraud, while previously suspected, would have been confirmed." (Emphasis added.) And Tony Pua in this regard was quoted to say:

In fact, had Datuk Hasan Arifin shared the Bank Negara letter with the PAC members, a whole new front of investigations would have been opened, including summoning Jho Low to testify before the PAC. Instead, he lied to the PAC members claiming that the Bank Negara letter was intended for his eyes only. This was despite the letter clearly making reference to the information being provided to the PAC for deliberations. (Emphasis added.) 
With Hasan accused for "obstructing the parliamentary investigation into 1MDB", Tony Pua claimed that Hasan's position as the PAC chairman was no longer acceptable. He said that Malaysians "can no longer trust him to carry out his role honestly, professionally and with integrity". He was also quoted to say: "We now call upon Hasan to resign as the chairman of the PAC because he has brought disrepute to the committee and disgraced the Parliament."

Separately the failure for 1 MDB to submit its overseas bank statements, the missing attendees in panel hearings and the deletion of a significant sentence from the final version of the PAC report should be serious enough cases for the discerning minds to have a considerable doubt in the quality of both the fact finding process undertaken and the report issued by the PAC on 1MDB - but combined? And what more when there were around several more cases of one thing or another similar to these three handicaps providing the very same conclusions? All in all, it appears that with its report and investigative work on the $1 \mathrm{MDB}$ filled with question marks all over them, the PAC just like so many other institutions in the country for years and years prior to the general election in May 2018 (and to some good extent post-GE14 too as alluded to in Part I of the case study under the heading "Obstruction of Justice"!) have failed to fulfill the roles that society has placed upon them.

But it appears that this is not the story unique to the 1MDB sad and sickening saga, for there have been numerous other cases earlier where such had taken place too. And invariably all have at the end resulted with the main culprits who are members of the nation's powerful elite class or those closely associated with them to have more often than not got away scot-free time and time again - or at worst suffer minimal forms of punishment which fail to be equitable considering the wrong which they committed. But to put all the blame squarely on the backs of these elite members appears to be a little unjust considering the fact that their hold on power is directly related to the undying support from a significant swath of the Malaysian people who appear unwilling to fathom that the elite has been quite good in manipulating them from day one... Really, it takes two to tango.

All in all, it is perhaps safe to say that in all this there is a familiar Malaysian story which can be summed up as governance breaking down (or in many cases non existent in the first place from the very beginning?) at the level of both organizations and overseeing institutions of concern - whereas on paper the concerned code of conducts, standards, rules and regulations and whatnot look neat and proper. But then there is no surprise regarding the latter since to a large extent these are nothing but imports from the western developed countries! And any attempt to have these imports transplanted into the Malaysian society shall meet with failures considering the fact that there is around a social, economic and political surrounding and historical antecedents of all that is important which are poles apart to those found in the developed countries in the west.

And, with the $1 \mathrm{MDB}$ providing the conclusive evidence that the imports were hardly in action, Malaysia in early December 2017 was quite justly brought to world wide shame when the then US Attorney General Jeff Sessions (at the Global Forum on Asset Recovery in Washington DC) had labeled the case of $1 \mathrm{MDB}$ as "kleptocracy at its worst"! But there are some lights at the end of the tunnel. As he had put it in the next breath ("Jeff Session calls", 2017): "Today, the US Department of Justice (DOJ) is working to provide justice to the victims of this alleged scheme." 
As to what exactly is kleptocracy, note the following coming from Lim Kit Siang (Kit Siang, 2016):

The term "kleptocrat" was only coined in the late 1990s to describe African dictators like Joseph Mobutu, Sani Abacha and Robert Mugabe plundering their own countries. ... Typically this system involves the embezzlement of state funds at the expense of the wider population, sometimes without even the pretence of honest service. Kleptocracies are generally associated with dictatorships, oligarchies, military juntas, or other forms of autocratic and nepotist governments in which external oversight is impossible or does not exist. Many kleptocratic rulers secretly transfer public funds into hidden personal numbered bank accounts in foreign countries to provide for themselves if removed from power. (Emphasis added.)

Later in the piece, Lim Kit Siang had this mentioned too:

Malaysia is the latest nation to gain the infamous epithet of a "global kleptocracy" - after the US Department of Justice (DOJ) lawsuits on July 20 for the forfeiture of over US\$1 billion of assets in the US, UK and Switzerland from over US\$3 billion embezzlement, misappropriation and moneylaundering of $1 \mathrm{MDB}$ funds, and after several countries like Singapore and Switzerland had taken action against banks, financial institutions and their staff in their countries for being implicated in the international conspiracy on money-laundering of $1 \mathrm{MDB}$ funds.

Also, it should be worth noting what Syed Farid Alatas from the University of Singapore had put forward in early March 2017 (Syed Farid Alatas, 2017):

In his pioneering work, The African Predicament, published in 1968, sociologist Stanislav Andreski describes how corruption was so pervasive in African states such that "politics becomes a strictly money-making activity". Politics was basically the only game in town. Politicians and bureaucrats were the main accumulators of capital rather than the private sector. They accumulated capital through corrupt practices involving bribery, extortion and nepotism. Such a polity was defined by Andreski as a kleptocracy. Kleptocracy is a system of government defined by corruption. (Emphasis added.)

Next, he revealed:

Although Andreski wrote decades ago about kleptocracy, it is only more recently that this type of polity has received serious attention. Of note is the US Department of Justice's Kleptocracy Asset Recovery Initiative. This is tasked with identifying and seizing foreign assets held by corrupt foreign leaders in the US.

And inevitably Malaysia came into the picture in this writing of his where he mentioned:

Last year, the DoJ filed a civil forfeiture complaint against assets that it alleged had been bought with money stolen from the sovereign wealth fund, 1Malaysia Development Bhd. The DoJ claimed that more than US\$3.5 billion was misappropriated from the fund. It filed the 144-page complaint in federal court in Los Angeles targeting about US\$1 billion in assets located in the US, the UK and Switzerland. The assets include mansions and penthouses, a US\$35 million executive jet and artwork. The DoJ claimed the assets are "traceable to an international conspiracy to launder money misappropriated from 1MDB". This is said to be the biggest forfeiture action since the Kleptocracy Asset Recovery Initiative was set up by the DoJ in 2010.

Enough said. 


\subsection{Clause 117 of 1MDB's memorandum and articles of association (M\&A)}

What did Clause 117 of the 1MDB's M\&A mean to the concerned parties in the then government and the opposition parties? Well, it appears that it was really considered quite significant by the latter! In The Malaysian Insider in late May 2015 ("Najib pretending", 2015) the following was mentioned: "Clause 117 of the memorandum, which was exposed by news portal Malaysiakini, showed that the prime minister's written approval was needed for any $1 \mathrm{MDB}$ deals, including its investments and restructuring exercises." It is notable too that in the same news report, the following was mentioned:

Petaling Jaya Utara MP Tony Pua today said the document only cemented that Najib was entirely responsible for problems surrounding the state investment vehicle including its RM42 billion debt. ... He said this contradicted what Putrajaya said, that Najib as prime minister was "not involved in the daily operations of $1 \mathrm{MDB}$, which is run by a professional and experienced team".

Related to this, note the quotation coming from Tony Pua:

Even in Najib's letter of demand sent to me on November 21, 2014, over my alleged defamatory statements with regard to $1 \mathrm{MDB}$, his lawyers stated unequivocally that 'contrary to your defamatory statements... our client being the chairman of the board of advisors of 1MDB only renders advice to the board of directors of $1 M D B$ who is tasked for the management and operation of 1MDB'.

And, as far as Tony Pua was concerned, the presence of Clause 117 had led a certain someone to pretend that all was well with $1 \mathrm{MDB}$. As Tony Pua put it: "Najib should drop all pretence of ignorance and give up the farcical charade that $1 \mathrm{MDB}$ is a healthy and salvageable company because he is only acting to deny his own culpability and protect his own interest in the matter."

Also note that on the very same date theedgemarkets.com had filed two crystal clear news reports regarding the same matter. In one the following was mentioned (Blemin, 2015):

1Malaysia Development Bhd's (1MDB) memorandum and articles of association (M\&A) suggests that Prime Minister Datuk Seri Najib Razak is a key decision maker in the company, according to opposition lawmaker Rafizi Ramli. PKR vice-president Rafizi said clause 117 of 1MDB's M\&A linked Najib to the investment decisions, and debt of the Malaysian government's wholly-owned entity. ... Najib, who is the Finance Minister, is also chairman of 1MDB's board of advisors. ... Rafizi said the revelation of article 117 meant the prime minister was directly involved in 1MDB's important transactions. Rafizi said the M\&A was adopted at 1MDB's extraordinary general meeting on Aug 11, 2009. Najib became Malaysia's sixth prime minister on April 3, 2009. (Emphasis added.)

As for the other news report ("Delay 11MP debate", 2015):

DAP today has demanded for an immediate halt to the parliamentary debate on the 11th Malaysia Plan to make way for Prime Minister Datuk Seri Najib Razak to provide a ministerial statement on his role in 1Malaysia Development Berhad (1MDB). Its parliamentary leader, Lim Kit Siang, said this should then be followed by a two-day debate, tantamount to whether Najib still enjoyed the confidence of the Parliament. He said Najib had been caught "red-handed" for saying that as the $1 M D B$ advisory board chairman, he was not responsible for the management of operations within the state investment vehicle. Now with leaked documents showing that the PM had the final say over any 
INTERNATIONAL JOURNAL OF ACADEMIC RESEARCH IN BUSINESS AND SOCIAL SCIENCES

Vol. 9, No. 3, March, 2019, E-ISSN: 222 2-6990 @ 2019 HRMARS

"financial commitment" undertaken by 1MDB's precursor Terengganu Investment Authority (TIA), Najib must give answers, Lim said. (Emphasis added.)

A couple of days later, when talking about the need for the then prime minister Datuk Seri Najib Razak and second finance minister Datuk Seri Ahmad Husni Hanadzlah to be "fair" to the federal cabinet members by giving them enough time to study and understand the roadmap to save debt-ridden 1MDB before a decision was made on it, the DAP senior party leader Lim Kit Siang had again made it clear as to the importance of Clause 117. In The Malaysian Insider, he was quoted to say ("Give cabinet more time", 2015):

The 35 ministers in the Najib Cabinet should be given adequate time to understand and study what the Save 1MDB Roadmap implies, especially as they had so far been kept in the dark about the most vital aspect of the $1 \mathrm{MDB}$ scandal - that the prime minister is the final approving authority for all $1 M D B$ deals, transactions and investments in the past six years. Why was this important aspect of the prime minister's direct role as final approving authority of any $1 M D B$ deal, transaction or investment not brought to the attention of the Cabinet, Parliament and the public? (Emphasis added.)

And note also that in the last few lines of the news report, the following was among others mentioned:

He urged Najib, who is also finance minister, to come clean with the Cabinet and "tell all" about his role and dealings in $1 \mathrm{MDB}$ since it began operations. This includes the number of times each year since 2009 that Najib had acted under Clause 117 of the 1MDB M\&A Agreement which stipulates that the prime minister must give his "written approval" for any 1MDB deals, including the firm's investments. Lim also said Najib should reveal the details of every such decision and whether the prime minister had personally given "written approval" under Clause 117 of the 1MDB M\&A Agreement for deals between the state-owned company and PetroSaudi International, Good Star Limited, UBG, Goldman Sachs, Gobi Coal and Energy Limited, as well as the Cayman Islands fund.

In the next few days following the publication of these news reports, another news report came out showing the great significance placed upon the contents of clause 117. In the Malaysiakini the following was mentioned early on (“MP tells Najib", 2015):

The prime minister has been told to recuse himself from any further involvement in the probe into the "monster 1Malaysia Development Bhd's (1MDB) scandal" following indications of his role in the company. Petaling Jaya Utara MP Tony Pua said this following revelations [by PKR secretary-general Rafizi Ramli at a Parliament press conference the day before] that Prime Minister Najib Razak is a key decision maker in the company according to $1 \mathrm{MDB}^{\prime}$ 's memorandum and articles of association (M\&A).

Next, in that very same news report, Tony Pua was quoted to say:

With this confirmation of 1MDB's M\&A, all the responsibility over the colossal RM42 billion of debt and billions of ringgit of losses and missing cash falls directly and entirely on the shoulders of Najib Razak. He not only signed off all decisions, he was involved every step of the way. As a result, we demand that Najib Razak recuse himself from any further involvement in all decisions over the investigations of the monster $1 M D B$ scandal. Firstly, he must stop taking charge over the direction and manner the investigations are carried out. Secondly, the Auditor-General's Office, which is a 
department under the Ministry of Finance, must also stop reporting to the prime minister, who is also the finance minister, on its findings and investigations. ... This is to prevent any attempt by the prime minister to effect any transactions to cover up any incriminating misdeeds which took place in the past. (Emphasis added.)

As for The Malaysian Insider, on the very same day that that news report from the Malaysiakini came out, Tony Pua was quoted to say the following in its news report ("Najib must not be involved", 2015): "If Najib were to continue his involvement in the investigations as well as 1MDB's business decisions, the integrity and trustworthiness of any reports produced will be questioned and the public interest in the matter will be severely jeopardized." (Emphasis added.) Hence, Tony Pua had next made a number of suggestions. As mentioned in the news report:

He proposed that Deputy Prime Minister Tan Sri Muhyiddin Yassin be given immediate full authority over the direction of investigation of 1 MDB because of Najib's direct implication in the transactions of $1 \mathrm{MDB}$. He added that the Auditor-General must be directed to report directly to the Public Accounts Committee on its findings, bypassing Najib to avoid any potential conflict of interest. ... Pua said all major investments, restructuring and business decisions of 1MDB should be approved directly by the Cabinet and not Najib alone as dictated in the 1MDB's Memorandum and Articles of Association.

Considering all that which transpired in late May 2015, one could perhaps be mistaken to think that Clause 117 of the $1 \mathrm{MDB}^{\prime}$ s M\&A would have stopped to become an issue anymore. Alas, that appears not to be the case for two years later - with or without Clause 117 - the 1MDB's sick and debilitating saga continued unabated. As Tony Pua had stated out in his media statement (Pua, 2017):

It should be recalled that one of the biggest controversies over the 1MDB scandal was the powers granted to the Prime Minister to make all final key decisions in the investment company. Clause 117 of 1MDB's Memorandum of Articles and Association dictates that the Prime Minister must give his "written approval" for any of 1MDB's deals, including the firm's investments or any bid for restructuring. It was Dato' Seri Najib Razak who gave the ultimate approval for all the billions of ringgit of lost investments carried out by $1 \mathrm{MDB}$ with Petrosaudi International Limited and Aabar Investment PJS Limited. The controversial clause has since been deleted upon recommendation by the Public Accounts Committee. However, it appears that Dato' Seri Najib Razak is still calling the shots behind the scene, bypassing key Treasury guidelines, as well as all forms of corporate governance and accountability which we have demanded to avoid a repeat of the 1MDB imbroglio. (Emphasis added.)

The media statement by Tony Pua was of course concerned with the question mark over who gave the authorization to terminate the agreement for the sale of Bandar Malaysia to the consortium led by Iskandar Waterfront Holdings. As stated Tony Pua early on in the media statement:

Based on Malaysiakini's report entitled "Arul is against termination of Bandar M'sia deal", government sources told the news portal that the RM7.41 billion deal was terminated without notifying Arul Kanda, the President and CEO of $1 \mathrm{MDB}$. However, at the material times, Arul Kanda was also the Chairman of Bandar Malaysia Sdn Bhd as well as a Board of Director of TRX City... Since Arul Kanda was oblivious to the entire termination exercise, it meant that the Board of Directors of both TRX City and Bandar Malaysia never deliberated and made a decision on the matter involving a 
whopping RM7.41 billion transaction. ... The question then arises as to whether Dato' Seri Najib Razak made the unilateral decision to terminate the agreement.

Next, Tony Pua had raised the following questions: "If so, it should be clarified as to what powers does the Finance Minister have to make material and critical decisions of Government companies unilaterally, by-passing the companies' board of directors? Did Dato' Seri Najib Razak abused his powers as the Finance and Prime Minister to terminate the IWH agreement?"

All in all, regardless of whether or not there is around Clause 117, it is perhaps safe to say that as far as the $1 \mathrm{MDB}$ was concerned the most powerful person was the then prime minister! And yet the PAC seemed to have burnished the then prime minister to be whiter than white in its $1 \mathrm{MDB}$ report! Hilariously cringe worthy?

\section{Decision Time - What Say You?}

With all the questions raised through the years and the different sorts of answers coming in that have brought little satisfaction to many, now it is your turn as the case's readers to decide on which side you are on. Is it the side that says the $1 \mathrm{MDB}$ is just a misunderstood company that is troubled by one thing or other such as wrong business model or poor corporate governance that some companies the world over do go through some time. In short, what happened was nothing unusual. It happened or is happening within so many companies past and present in various parts of the world!

Or, are you on the side that believes that $1 \mathrm{MDB}$ is through and through a vehicle for the stealing of billions by those whose greed knew no bounds and who had never felt even an iota of concern for the Malaysian masses which shall have to bear the consequences for years and years to come for what they had not played a part of. And in relation to this, you have the view that wrong business model, poor corporate governance and the like were just excuses used by concerned parties to avoid them from saying that there was indeed fraud taking place?

Or, could it be that you do agree that there was fraud happening and that wrong business model, poor corporate governance and the like were actually interrelated moves undertaken by the fraudsters from within and outside $1 \mathrm{MDB}$ in their collusions to perpetrate their massive betrayal against Malaysia and its people? In other words, without the wrong business model, poor corporate governance and the like there would not be fraud. Furthermore, there is the distinctive belief in your part that the intention to commit fraud was ever present even before the 1MDB was established - and what finally took place with the so called wrong business model, poor corporate governance and the like were nothing more than machinations to ensure the completion of the mission in the shortest time possible.

After all, as the last prophet of Islam has said over fourteen centuries ago: there is niat (intention) in everything! And the niat to commit fraud should be clear to all and sundry after having gone through what had transpired in the $1 \mathrm{MDB}$ over the years - and in this very case study so many of these things were reflected in the various lists of questions presented earlier under the questions section in Part I. And such conviction should be strengthened after having gone through all that laid out in the answers section that come right after which provides the picture that only people with dubious character would have resorted to those kinds of answers that included efforts to obstruct justice and intimidate others from both inside and outside the country!

Or, perhaps you are not in either side - instead you have your own more mundane or otherwise quite extraordinary views of things? And what could this be? Pray tell. 
Now, whatever is your stance do try to figure out the following: what is your view as the root cause(s) to whatever you believe has troubled $1 \mathrm{MDB}$ and has led to $1 \mathrm{MDB}$ bringing a lot of problems to all and sundry? Assuming that you believe that there was fraud perpetrated in 1MDB in the form of both embezzlements of 1MDB funds and falsification of 1MDB's financial statements year after year, do you believe that the concept of fraud triangle can explain it all? If not, why? And can you suggest any other concept, theory or model as the alternative to explain it all? Is there another case like 1MDB anywhere that you can think of and which comparison can be made so that better lessons can perhaps be learnt by all? Also, what do you think can be done to ensure that there shall never be any more enterprises like $1 M D B$ in the future? Perhaps the right actions could be taken at the various individual, organizational, national and international governance levels and when it concerns the social, political and economic spheres of the country? Pray tell, what may these be? And finally what do you think the future shall bring as far as the fields of corporate governance, accounting and auditing in the country are concerned and also as far as the country as a whole? Is there still hope for Malaysia?

Before the case study comes to an end note that the next one or two case studies on 1MDB's corporate governance shall attempt to explore certain aspects capable in explaining the failure of governance found inside and outside the 1MDB. And this also happens to be the focus for the last few questions above. But, as far as the national governance outside the 1MDB is concerned, it seems that there is a need to take caution since how does one explain the fact that in some places the seemingly incongruence between imports on one hand and the local context and way of doing things throughout the ages on the other hand is not able to stop the so called imports to function as well as or better than what can be found in their countries of origins? One can perhaps think of Singapore, Hong Kong and Taiwan and of course Japan and South Korea in this regard. In these places thus one can safely surmise that there is a limit to the impact that such frustrating context and history may have on the functioning of those imports - or perhaps there exist some crucial factors in the area surrounding those imports compensating the negative influence coming from such context?

And finally when it concerns the proposition that the less than healthy context may have negative impact on imports, the author in the last two decades since the completion of his PhD has published a series of papers which readers may be interested to peruse. These papers may be placed under two categories: one on external audit and related areas in Malaysia covering period from 1957 to 1997 and the other on internal audit at the level of local, state and federal governments of Malaysia. The former is based upon his PhD thesis which by the way was published almost intact in the form of a monograph in 1999 (Azham, 1999), while the latter is concerned with a total of three separate studies conducted in the previous decade by his research teams. In regard to the former, the papers of concern are Azham (2014a), Azham (2014b), Azham (2013), Azham (2009), Azham (2007) and Azham et al. (2006). As for the latter: Azham, Mohd.-Hadafi, Sazali et al. (2012), Azham, Siti-Zabedah, Mohd.-Hadafi, Mohd.-Hadzrami et al. (2012), Azham, Aidi, Sazali et al. (2011), Azham et al. (2009) and Azham et al. (2007).

Note that in Azham, Mohd.-Hadafi, Sazali et al. (2012) which is the very last paper published on the series of internal audit research studies, the section on conclusions is also concerned with what was concluded earlier for the study on external audit to emphasise the importance of context outside the audit arena for audit utility and efficacy. Also note that in Azham, Heang and West (2011), readers shall find one of the so called imports that comes in the form of accounting professionalisation in Malaysia during the early years after independence is discussed at length. 
INTERNATIONAL JOURNAL OF ACADEMIC RESEARCH IN BUSINESS AND SOCIAL SCIENCES

Vol. 9, No. 3, March, 2019, E-ISSN: 222 2-6990 ¿ 2019 HRMARS

\section{References}

1MDB a small issue involving one firm, says Treasury. (2015, May 19). The Malaysian Insider. Retrieved from https://www.theedgemarkets.com/article/1mdb-small-issue-involving-one-firm-saystreasury

1MDB unsustainable from the start, minister admits to CNBC. (2016, April 4). Malaysiakini. Retrieved from https://www.malaysiakini.com/news/336386

1MDB: Abandon ship - Sir Wenger J. Khairy. (2015, March 5). The Malaysian Insider. Retrieved from http://www.themalaysianinsider.com/sideviews/article/1mdb-abandon-ship-sir-wenger-j.-khairy

1MDB's problems no small matter, DAP tells Treasury man. (2015, March 20). The Malaysian Insider. Retrieved from https://www.theedgemarkets.com/article/1mdb\%E2\%80\%99s-problems-nosmall-matter-dap-tells-treasury-man

Ahmad Naqib, I. (2016a, April 12). PM Najib: 1MDB's 'real legacy' seen in TRX, Bandar Malaysia. Retrieved from https://www.theedgemarkets.com/node/271796

Ahmad Naqib, I. (2016b, April 27). 1MDB's Arul: I never admitted there was fraud. Retrieved from https://www.theedgemarkets.com/article/1mdbs-arul-i-never-admitted-there-was-fraud

Ahmad Naqib, I. (2016c, April 7). Najib must be held accountable for 1MDB, says Tony Pua. Retrieved from https://www.theedgemarkets.com/article/najib-must-be-held-accountable-1mdb-saystony-pua

Ahmad Naqib, I. (2016d, April 7). PAC and AG's 1MDB finding 'confirms gross mismanagement' - Tony Pua. Retrieved from https://www.theedgemarkets.com/article/pac-and-ags-1mdb-findingconfirms-gross-mismanagement-tony-pua

Ahmad Naqib, I. (2016e, April 7). PAC deputy chair urges MPs to take action against 1MDB's management. Retrieved from https://www.theedgemarkets.com/article/pac-deputy-chair-urgesmps-take-action-against-1mdbs-management

Alyaa, A. (2016a, April 15). Resign for 'stupid' signing of 1MDB docs without reading, Dr M tells Najib. Malaysiakini. Retrieved from https://www.malaysiakini.com/news/337898

Alyaa, A. (2016b, August 21). From squatter boy to minister, Johari thanks Dr M but is loyal to Najib. Malaysiakini. Retrieved from https://www.malaysiakini.com/news/353107

Alyaa, A. (2016c, January 1). '1MDB's mismanagement still unaddressed'. Malaysiakini. Retrieved from https://www.malaysiakini.com/news/325180 
INTERNATIONAL JOURNAL OF ACADEMIC RESEARCH IN BUSINESS AND SOCIAL SCIENCES

Vol. 9, No. 3, March, 2019, E-ISSN: 222 2-6990 @ 2019 HRMARS

Amarthalingam, S. (2016, July 21). PM can no longer hide in silence about $1 M D B$, says Azmin. Retrieved from https://www.theedgemarkets.com/article/pm-can-no-longer-hide-silence-about-1mdbsays-azmin

Anisah, S. (2015a, March 9). Enough proof to charge Jho Low, Najib and ex-1MDB chief, says PKR. The Malaysian Insider. Retrieved from https://www.theedgemarkets.com/article/enough-proofcharge-jho-low-najib-and-ex-1mdb-chief-says-pkr

Anisah, S. (2015b, May 27). No more delays, PAC warns 1MDB's Arul Kanda. The Malaysian Insider. Retrieved from https://www.theedgemarkets.com/article/no-more-delays-pac-warns-arul-kanda

Azham, A., Roszaini, H., \& Muhammad Hudaib. (2006). Episodes in the Malaysian auditing saga. Managerial Auditing Journal, 21(7), 684-701.

Azham, M.A. (1999). Political Economy of External Audit in Malaysia, 1957-1997, Sintok: Universiti Utara Malaysia Press.

Azham, M.A. (2007). Accounting in Malaysia in the post-New Economic Policy (NEP) era. Issues in Social and Environmental Accounting, 1(1), 109-148.

Azham, M.A. (2009). The New Economic Policy and the accounting profession in Malaysia: A case of a misfit. Indonesian Management and Accounting Research, 8(1), 47-89.

Azham, M.A. (2013). Phantasmagoric accounting in Malaysia: A case study of "the triumph of hope over experience"? International Journal of Accounting and Financial Reporting, 3(2), 12-68.

Azham, M.A. (2014a). Ethnicity, foreign investments and strong pragmatic government: Towards interpreting accounting progress in Malaysia. Journal of Public Administration and Governance, 4(3), 245-336.

Azham, M.A. (2014b). Politics and audit in Malaysia. Journal of Public Administration and Governance, $4(4), 29-66$.

Azham, M.A. (2018). IMDB: Corporate governance going berserk? Part I. International Journal of Academic Research in Business and Social Sciences. 8(12), 1861-1946.

Azham, M.A., Aidi, A., Azharudin, A., Mohamad-Zulkurnai, G., Gloeck, J.D., \& Lee, T.H. (2009). Internal audit in the federal organizations: Is there light at the end of the long dark tunnel? Southern African Journal of Accountability and Auditing Research, 9(1), 23-38.

Azham, M.A., Aidi, A., Sazali, S., Azharudin, A., Ram-Al-Jaffri, S., Mohd.-Hadafi, S. Aryati- Juliana, S., \& Ahmad-Zamil, A.K. (2011). Internal audit in the statutory bodies and government-linked companies 
INTERNATIONAL JOURNAL OF ACADEMIC RESEARCH IN BUSINESS AND SOCIAL SCIENCES

Vol. 9, No. 3, March, 2019, E-ISSN: 222 2-6990 (C) 2019 HRMARS

of Malaysia: The never ending story! Journal of Public Administration and Governance, 1(2), 256297.

Azham, M.A., Gloeck, J.D., Azharudin, A., Aidi, A., \& Mohd.-Hadafi, S. (2007). Internal audit in the state and local governments of Malaysia. Southern African Journal of Accountability and Auditing Research, 7(1), 25-57.

Azham, M.A., Mohd.-Hadafi, S., Sazali, S., \& Gloeck, J.D. (2012). Internal audit in the statutory bodies and government-linked companies of Malaysia (2005 - 2008): Dream of dreams? Southern African Journal of Accountability and Auditing Research, 13(1), 1-17.

Azham, M.A., Siti-Zabedah, S., Mohd.-Hadafi, S., Mohd.-Hadzrami, H.R., Mohd-Syahrir, R., \& Gloeck, J.D. (2012). Internal audit in the federal government organizations of Malaysia: The good, the bad and the very ugly? Asian Journal of Business and Governance, 2(1), 68-110.

Azham, M.A. Heang, L.T., \& West, B. (2011). External influences on the development and professionalisation of accounting in Malaysia, 1957-1969. Indonesian Management and Accounting Research, 10(2), 23-50.

Barrock, J., \& Fong, K. (2016, May 12). Cover Story: His job is not quite done yet. The Edge Malaysia Weekly. Retrieved from https://www.theedgemarkets.com/article/cover-story-his-job-not-quitedone-yet

Blemin, C. (2015, May 27). 1MDB's memorandum and articles of association suggests PM Najib a key decision maker - Rafizi. Retrieved from https://www.theedgemarkets.com/article/1mdbsmemorandum-and-articles-association-suggests-pm-najib-key-decision-maker-rafizi

Chan, J. (2017, June 19). How the 1MDB blockbuster starring Jho Low is dwarfing even Hollywood. theedgemarkets.com.sg. Retrieved from http://www.theedgemarkets.com/article/how-1mdbblockbuster-starring-jho-low-dwarfing-even-hollywood

Chie, K.G. (2016a, May 25). Gov't never said 1MDB is good business, claims Johari. Malaysiakini. Retrieved from https://www.malaysiakini.com/news/342842

Chie. K.G. (2016b, July 1). Johari pledges to resolve 1MDB issue 'transparently'. Malaysiakini. Retrieved from https://www.malaysiakini.com/news/347290

Chiew, S. (2017, June 19). How did Jho Low allegedly spend the money from 1MDB? theedgemarkets.com.sg. Retrieved from https://www.theedgemarkets.com/article/how-did-jholow-allegedly-spend-money-1mdb 
Chye, K.T. (2016, April 27). Will it be checkmate for Arul Kanda? Malaysiakini. Retrieved from https://www.malaysiakini.com/columns/339323

Come clean on all allegations to redeem 'sins', Arul Kanda urged. (2016, April 25). Malaysiakini. Retrieved from https://www.malaysiakini.com/news/339140

Delay $11 \mathrm{MP}$ debate for Najib to declare $1 \mathrm{MDB}$ role, says Kit Siang. (2015, May 27). The Malaysian Insider. Retrieved from https://www.theedgemarkets.com/article/delay-11mp-debate-najibdeclare-1mdb-role-says-kit-siang

Did Najib okay 1MDB duo's no-show at PAC hearing, asks DAP. (2015, May 26). The Malaysian Insider. Retrieved from https://www.theedgemarkets.com/article/did-najib-okay-1mdbduo\%E2\%80\%99s-no-show-pac-hearing-asks-dap

Dr Mahathir's claims show his contempt for investigations, says 1MDB. (2015, December 3). The Malaysian Insider. Retrieved from https://www.theedgemarkets.com/article/drmahathir\%E2\%80\%99s-claims-show-his-contempt-investigations-says-1mdb

Editing of sentences doesn't affect PAC report, says Hasan. (2016, April 20). Bernama. Retrieved from https://www.malaysiakini.com/news/338456

Ex-1MDB CEO stresses nothing illegal happened on his watch. (2016, April 7). Bernama. Retrieved from https://www.malaysiakini.com/news/336922

Freeze Jho Low's assets, DAP tells police (2015, April 30). The Malaysian Insider. Retrieved from https://www.theedgemarkets.com/node/199013

Fuentes, S. (2015, April 24). Pua: No more lies from Najib on 1MDB. Free Malaysia Today. Retrieved from http://www.freemalaysiatoday.com/category/nation/2015/04/24/pua-no-more-lies-fromnajib-on-1mdb/

Fui, C.S. (2016a, April 12). DAP demands police to investigate and arrest all parties involved in 1MDB scam. Retrieve from https://www.theedgemarkets.com/article/dap-demands-police-investigateand-arrest-all-parties-involved-1mdb-scam

Fui, C.S. (2016b, May 17). Pua claims cover up by PM on 1MDB failing to furnish bank statements to Auditor General. Retrieved from https://www.theedgemarkets.com/article/pua-claims-cover-pm$1 \mathrm{mdb}$-failing-furnish-bank-statements-auditor-general

Gasper, D.T. (2015, April 24). Answer claims of false documents, says Dr M. The Star Online. Retrieved from https://www.thestar.com.my/news/nation/2015/04/24/answer-claims-of-false-documentssays-dr-m/ 
INTERNATIONAL JOURNAL OF ACADEMIC RESEARCH IN BUSINESS AND SOCIAL SCIENCES

Vol. 9, No. 3, March, 2019, E-ISSN: $2222-6990$ C 2019 HRMARS

Give Cabinet more time to study 1MDB roadmap, says Kit Siang. (2015, May 29). The Malaysian Insider. Retrieved from http://www.theedgemarkets.com/article/give-cabinet-more-time-study-1mdbroadmap-says-kit-siang

Gunasegaram, P. (2013, March 28). 1MDB loans to PetroSaudi put nearly RM6 billion at risk. KiniBiz. Retrieved from http://www.kinibiz.com/story/issues/11725/1mdb-loans-to-petrosaudi-putsnearly-rm6-billion-at-risk.html

Gunasegaram, P. (2014, March 5). Do we need 1MDB at all? KiniBiz. Retrieved from http://www.kinibiz.com/story/tigertalk/74945/do-we-need-1mdb-at-all.html

Gunasegaram, P. (2016, April 12). 10 reasons why Najib is accountable on 1MDB. Malaysiakini. Retrieved from https://www.malaysiakini.com/columns/337446

Hazlan, Z. (2012, June 27). PAC fails to obtain 1MDB investment documents. Malaysiakini. Retrieved from https://www.malaysiakini.com/news/202038

Hun, C.J. (2016a, April 20). Is PAC chairman Hasan questioning accuracy of Bank Negara's 1MDB findings? - Tony Pua. Retrieved from https://www.theedgemarkets.com/article/pac-chairmanhasan-questioning-accuracy-bank-negaras-1mdb-findings-tony-pua

Hun, C.J. (2016b, April 21). PAC chief urged to reopen probe after 'delete' admission. The Edge Financial Daily. Retrieved from https://www.theedgemarkets.com/article/pac-chief-urged-reopen-probeafter-\%E2\%80\%98delete\%E2\%80\%99-admission

Jeff Sessions calls Malaysia's 1MDB scandal 'kleptocracy at its worst'. (2017, December 5). Retrieved from https://www.reuters.com/article/us-malaysia-scandal-doj/jeff-sessions-calls-malaysias$1 \mathrm{mdb}$-scandal-kleptocracy-at-its-worst-idUSKBN1DZOMX

Jho Low denies wrongdoing claims linked to 1MDB (2017, July 14). Bloomberg/The Edge Financial Daily. Retrieved from https://www.theedgemarkets.com/article/jho-low-denies-wrongdoing-claimslinked-1mdb

Johari, A.G. (2017, March 20). Give it a rest, says Johari in open letter to Tony Pua. Malaysiakini. Retrieved from https://www.malaysiakini.com/news/376351

Johari: We can't press charges on 1MDB without a full picture. (2017, March 17). Malaysiakini. Retrieved from https://www.malaysiakini.com/news/376068

Khairie, H.A. (2015, March 21). 1MDB issues are no joke. KiniBiz. Retrieved from http://www.kinibiz.com/story/exclusive/155353/1mdb-issues-are-no-joke.html 
INTERNATIONAL JOURNAL OF ACADEMIC RESEARCH IN BUSINESS AND SOCIAL SCIENCES

Vol. 9, No. 3, March, 2019, E-ISSN: 222 2-6990 (C) 2019 HRMARS

Kit Siang, L. (2016, October 7). 'Najib's meeting with one of the world's oldest kleptocrats is troubling'. Malaysiakini. Retrieved from https://www.malaysiakini.com/news/358228

Lakhsana, M. (2016a, April 8). Tony Pua: 1MDB's refusal to cooperate raises suspicions that 'billions of dollars' are indeed missing. Retrieved from https://www.theedgemarkets.com/article/tony-pua$1 \mathrm{mdbs}$-refusal-cooperate-raises-suspicions-billions-dollars-are-indeed-missing

Lakshana, M. (2016b, April 13). 1MDB could be a victim of fraud, says Arul Kanda. Retrieved from https://www.theedgemarkets.com/node/272318

Lakshana, M. (2016c, April 13). DAP's Pua accuses Arul Kanda of 'covering up' 1MDB-Aabar BVI scam. Retrieved from https://www.theedgemarkets.com/node/272133

Lakshana, M. (2016d, May 27). Pua: PAC chairman must resign for lying, suppressing evidence on 1MDB. Retrieved from https://www.theedgemarkets.com/article/pua-pac-chairman-must-resign-lyingsuppressing-evidence- $1 \mathrm{mdb}$

Lim, B.S. (2015, January 16). Story of the years: $1 \mathrm{MDB}$ - no more the elephant in the room. The Edge Malaysia Weekly. Retrieved from https://www.theedgemarkets.com/article/story-years-1mdb\%E2\%80\%93-no-more-elephant-room

Lim, B.S., \& Barrock, J. (2016, January 28). Cover story: It is mission accomplished at $1 \mathrm{MDB}$ for an RMC old boy. The Edge Malaysia Weekly. Retrieved from https://www.theedgemarkets.com/article/cover-story-it-mission-accomplished-1mdb-rmc-oldboy

Mahathir, M. (2015a, April 23). 1MDB. Retrieved from http://chedet.cc/?p=1672

Mahathir, M. (2015b, December 3). 1MDB clarifies. Retrieved from http://chedet.cc/?p=1931

Mahathir, M. (2015c, June 4). 1MDB restructure. Retrieved from http://chedet.cc/?p=1735

Mahathir. M. (2015d, June 5). How 1MDB money was invested. Retrieved from http://chedet.cc/?p=1744

Malaysia's Najib says "conscience clear" as funding scandal festers. (2015, December 8). Reuters. Retrieved from https://www.theedgemarkets.com/article/malaysias-najib-says-conscience-clearfunding-scandal-festers

Media urged to access info on 1MDB through Parliament's website. (2016, April 13). Bernama. Retrieved from https://www.malaysiakini.com/news/337625 
INTERNATIONAL JOURNAL OF ACADEMIC RESEARCH IN BUSINESS AND SOCIAL SCIENCES

Vol. 9, No. 3, March, 2019, E-ISSN: 222 2-6990 ¿ 2019 HRMARS

MP tells Najib to keep hands off 1MDB probe. (2015, May 28). Malaysiakini. Retrieved from https://www.malaysiakini.com/news/299897

Murugiah, S. (2016, April 11). He did no wrong? The Edge Malaysia Weekly. Retrieved from https://www.theedgemarkets.com/node/271381

Murugiah, S. (2017a, March 20). Johari must explain why AG's report on 1MDB remains classified, says DAP's Pua. Retrieved from https://www.theedgemarkets.com/article/johari-must-explain-whyag\%E2\%80\%99s-report-1mdb-remains-classified-says-dap\%E2\%80\%99s-pua

Murugiah, S. (2017b, March 21). Why has Putrajaya not claimed the US\$1 billion 1MDB's stolen assets seized by US DOJ?, asks DAP's Pua. Retrieved from https://www.theedgemarkets.com/article/whyhas-putrajaya-not-claimed-us1-billion-1mdb\%E2\%80\%99s-stolen-assets-seized-us-doj-asksdap\%E2\%80\%99s-pua

Muzliza, M. (2015, May 18). 1MDB RM42 billion now part of TRX, Bandar Malaysia land bank, says Najib. The Malaysian Insider. Retrieved from https://www.theedgemarkets.com/article/1mdb-rm42billion-now-part-trx-bandar-malaysia-land-bank-says-najib

'My job is done': 1MDB chief Arul Kanda says leaving embattled Malaysia state fund. (2016, March 31). Bloomberg. Retrieved from https://www.businesstimes.com.sg/government-economy/my-job-isdone-1mdb-chief-arul-kanda-says-leaving-embattled-malaysia-state-fund

Najib cannot disassociate himself from 1MDB, says Tony Pua. (2015, March 2). The Malaysian Insider. Retrieved from https://www.theedgemarkets.com/article/najib-cannot-disassociate-himself$1 \mathrm{mdb}$-says-tony-pua

Najib must appear in Parliament to explain scandals, says Kit Siang. (2015, November 6). The Malaysian Insider. Retrieved from https://www.theedgemarkets.com/article/najib-must-appear-parliamentexplain-scandals-says-kit-siang

Najib must not be involved in 1MDB probe, says DAP. (2015, May 28). The Malaysian Insider. Retrieved from https://www.theedgemarkets.com/article/najib-must-not-be-involved-1mdb-probe-saysdap

Najib must step down over 1MDB's 'disappeared' funds, says Dr M. (2015, April 23). The Malaysian Insider. Retrieved from http://www.theedgemarkets.com/article/najib-must-step-down-over1mdb\%E2\%80\%99s-\%E2\%80\%98disappeared\%E2\%80\%99-funds-says-dr-m 
INTERNATIONAL JOURNAL OF ACADEMIC RESEARCH IN BUSINESS AND SOCIAL SCIENCES

Vol. 9, No. 3, March, 2019, E-ISSN: 222 2-6990 ¿ 2019 HRMARS

Najib pretending all fine with 1MDB, says Pua. (2015, May 27). The Malaysian Insider. Retrieved from http://www.themalaysianinsider.com/malaysia/article/najib-pretending-all-fine-with-1mdb-sayspua

Najib: 1MDB's problems due to failure to issue IPO. (2016, May 11). Retrieved from https://www.theedgemarkets.com/article/najib-1mdbs-problems-due-failure-issue-ipo

Najib's continued silence on 1MDB damning, says Pua. (2015, April 28). The Malaysian Insider. Retrieved from http://www.themalaysianinsider.com/malaysia/article/najibs-continued-silence-on-1mdbdamning-says-pua

Najib's full speech at Invest Malaysia 2017 detailing the country's economic progress. (2017, July 25). The Star. Retrieved from https://www.thestar.com.my/news/nation/2017/07/25/najibs-fullspeech-at-invest-malaysia-2017-detailing-the-country-economic-progress/

Ng, E. (2015, January 15). 1MDB: SRC International no longer subsidiary. The Malaysian Insider. Retrieved from https://www.theedgemarkets.com/article/1mdb-src-international-no-longersubsidiary

Probe 1MDB directors for breach of fiduciary duties, says Cenbet. (2015, May 27). The Malaysian Insider. Retrieved from https://www.theedgemarkets.com/article/probe-1mdb-directors-breachfiduciary-duties-says-cenbet

Pua, T. (2016, May 26). If Johari is right, why didn't gov't shut down 1MDB earlier? Malaysiakini. Retrieved from https://www.malaysiakini.com/news/343006

Pua, T. (2017, May 11). Tony Pua: Who authorised termination of Bandar Malaysia deal? https://www.theedgemarkets.com/article/tony-pua-who-authorised-termination-bandarmalaysia-deal

Raja Kamarul Bahrin Shah, R. A. (2016, May 26). If T'ganu had foresight to back out of TIA, why not federal gov't? Malaysiakini. Retrieved from https://www.malaysiakini.com/news/343047

Ramesh, R. (2016, July 29). 1MDB: The inside story of the world's biggest financial scandal. The Guardian. Retrieved from https://www.theedgemarkets.com/article/1mdb-inside-storyworld\%E2\%80\%99s-biggest-financial-scandal

Run-Up to GE14: 'Issues are because of wrong business model, weak management and poor governance'. (2018, April 18). The Edge Malaysia Weekly. Retrieved from https://www.theedgemarkets.com/article/runup-ge14-issues-are-because-wrong-businessmodel-weak-management-and-poor-governance-0

Sarawak Report. (2016, April 23). The Writing on the Wall. Retrieved from http://www.sarawakreport.org/talkback/the-writing-on-the-wall/ 
INTERNATIONAL JOURNAL OF ACADEMIC RESEARCH IN BUSINESS AND SOCIAL SCIENCES

Vol. 9, No. 3, March, 2019, E-ISSN: 222 2-6990 ¿ 2019 HRMARS

Shahrol not only one to blame for 1MDB failures, says NGO. (2016, April 10). Malaysiakini. Retrieved from https://www.malaysiakini.com/news/337256

Stop lying and protecting Jho Low, DAP tells Najib. (2015, April 24). The Malaysian Insider. Retrieved from http://www.themalaysianinsider.com/malaysia/article/stop-lying-and-protecting-jho-lowdap-tells-najib

Surendren, S. (2015, April 24). Dr M asks PM what happened to RM27b 1MDB funds. The Edge Financial Daily. Retrieved from http://www.theedgemarkets.com/article/dr-m-asks-pm-what-happenedrm27b-1mdb-funds

Alatas, S. F. (2017, March 2). Against The Grain: Kleptocracy and criminology - how to study the state. The Edge Malaysia Weekly. Retrieved from https://www.theedgemarkets.com/article/againstgrain-kleptocracy-and-criminology-\%E2\%80\%94-how-study-state

Why has Najib refused to address Parliament on 1MDB? asks DAP's Pua. (2017, July 26). Retrieved from https://www.theedgemarkets.com/article/why-has-najib-refused-address-parliament-1mdbasks-daps-pua

Zikri, K. (2016, April 19). 'PAC chief cut out BNM statement on Good Star's owner'. Malaysiakini. Retrieved from https://www.malaysiakini.com/news/338356 